\title{
Impact of viral multiplex real-time PCR on management of respiratory tract infection: a retrospective cohort study
}

\author{
Lena M. Mayer ${ }^{1,4}$, Christian Kahlert ${ }^{2,4}$, Frank Rassouli ${ }^{3}$, Pietro Vernazza ${ }^{4}$ and Werner C. Albrich ${ }^{4 *}$
}

\begin{abstract}
Background: Significance and clinical utility of multiple virus detection by multiplex real-time polymerase chain reaction (rtPCR) in respiratory tract infection remain unclear.

Methods: This retrospective cohort study analyzed how virus detection affected clinical management. During a 27month period, clinical and laboratory information was collected from all children and adults in two Swiss tertiary centres whose respiratory samples were tested for respiratory viruses with a 16-plex rtPCR test.

Results: Pathogens were identified in 140 of 254 patients (55\%); of those patients, there was $\geq 1$ virus in 91 (65\%), $\geq 1$ bacterium in 53 (38\%), and $\geq 1$ virus and bacterium in 11 (8\%). Of 80 patients with viral infection, 59 (74\%) received antibiotics. Virus detection was associated with discontinuation of antibiotics in 2 of 20 adults (10\%) and 6 of 14 children (43\%). Overall 12 adults (34\%) and 18 children (67\%) were managed correctly without antibiotics after virus detection $(p=0.01)$. When taking biomarkers, radiologic presentations, and antibiotic pre-treatment into account, the impact of rtPCR and appropriateness of therapy for clinically viral infections increased to $100 \%$ in children and $62 \%$ in adults.
\end{abstract}

Conclusions: A substantial reduction of unnecessary antibiotic prescriptions seems possible. Appropriate application of rtPCR results in respiratory tract infections should be encouraged.

Keywords: Multiplex real-time PCR, Respiratory viruses, Antibiotic management

\section{Background}

Establishing the etiology of respiratory tract infections (RTI) is often difficult due to the lack of a diagnostic gold standard and the inability to detect the causative pathogen. A large proportion of RTI is believed to be caused by respiratory viruses [1-6]. With widespread availability of molecular methods such as multiplex realtime polymerase chain reaction ( $\mathrm{rtPCR}$ ), clinical workflow has changed dramatically and the sensitivity of viral diagnostics has increased remarkably compared to conventional methods [3, 7-13]. However, the significance of virus detection remains unclear as the presence of a virus does not prove causality. Many respiratory viruses can be carried by asymptomatic children $[4,6,14]$ and

\footnotetext{
* Correspondence: Werner.Albrich@kssg.ch

${ }^{4}$ Division of Infectious Diseases \& Hospital Epidemiology, Kantonsspital St.

Gallen, Rorschacherstrasse 95, 9007 St. Gallen, Switzerland

Full list of author information is available at the end of the article
}

can be shed over prolonged periods, thus discrimination between carriage and infection is challenging [13-15]. Viral infection was reported previously to predispose to bacterial super-infection and concerns about possible bacterial co-infection remain [3, 7-13, 16-19]. Ruling out a bacterial infection with traditional microbiological techniques is frequently impossible $[1,5]$. The predictive value of clinical signs to differentiate between viral and bacterial infection is also low [13, 17, 20-22]. On these grounds, clinical management of patients after respiratory virus diagnosis is controversial and surprisingly poorly studied. Overall, extensive yet often unnecessary use of antibiotics in RTI is common $[1,5,6]$. This adult and pediatric retrospective cohort study analyzed whether identification of a virus by multiplex rtPCR was associated with changes in the antibiotic treatment. 


\section{Methods}

\section{Study design and population}

This was a retrospective cohort study of all pediatric and adult in- and outpatients in whom a 16-plex rtPCR assay for respiratory viruses was performed for upper and lower RTI, from either the Kantonsspital St. Gallen or Children's hospital of Eastern Switzerland. Both hospitals are tertiary-care Swiss teaching hospitals with active infectious diseases consult services and easily accessible web-based local guidelines (www.guidelines.ch) for the treatment of community-acquired or hospital-acquired pneumonia. The guidelines are strongly recommended for use but not strictly reinforced, and include use of rtPCR as optional diagnostic in hospitalized patients, particularly with immune suppression. The study period was from September 2012 (when this assay was introduced) to November 2014. The documented application dates of anti-infective medication were matched with the date of rtPCR analysis in order to determine whether treatment was changed in response to rtPCR results. The main outcome of interest was whether antibiotic therapy was modified according to results of multiplex rtPCR. Secondary outcomes were prevalence and distribution of positive results of rtPCR, complications, length of stay (LOS), and antibiotic therapy depending on identified pathogens.

\section{Data collection}

To identify patients, the database of the Centre for Laboratory Medicine was searched. Medical records were retrospectively analyzed to obtain basic demographic, clinical, laboratory and radiological parameters and data on clinical management. All chest radiographs (CXR) and computed tomographies (CT) for adults and children were reviewed by a pulmonologist and a pediatrician, respectively.

\section{Clinical definitions}

rtPCR results were available within 24 hours after testing. The application dates of anti-infective medication as documented in the medical records were correlated with the day of, or the day after, rtPCR analysis in order to define whether treatment initiation or discontinuation was associated with the results of viral testing.

The identified pathogens were retrospectively determined as relevant by an infectious disease specialist who integrated all available information. Etiologies were divided in four mutually exclusive groups: (i) bacterial ( $\geq 1$ bacteria); (ii) viral ( $\geq 1$ respiratory viruses); (iii) mixed ( $\geq 1$ bacteria and $\geq 1$ respiratory viruses); or (iv) no pathogen (including fungi, non-respiratory virus, bacterial contaminant including coagulase-negative staphylococci, propionibacterium, corynebacterium, colonizing oral and respiratory flora). For some children, rapid detection tests (Alere BinaxNOW Influenza A\&B, Quidel QuickVue RSV Test) for respiratory syncytial virus (RSV) and influenza A/B virus were available. These results were additionally considered in forming the different groups.

For each patient, changes of antibiotic management, i.e. either starting or stopping antibiotics, were determined. All other situations were defined as no change.

Management was considered correct for viral infections if there was no antibiotic treatment before and after rtPCR or antibiotics were stopped after positive rtPCR results became available; for bacterial or mixed infections, if antibiotics were given before and after rtPCR or were started after a negative rtPCR result. Patients with an indication other than RTI for antibiotic therapy were excluded. For patients with febrile neutropenia without a specific focus, the antibiotic indication was defined as "other" because antibiotics would usually not be stopped despite a viral detection. If a patient underwent repeated testing for respiratory viruses within 3 weeks, only the first positive result was counted. If the time interval was longer or the detected viruses diverged, a different episode was presumed and analyzed separately [23].

To reflect clinical decision making in real-life situations, sub-analyses were performed. Cases without detection of bacteria (i.e. patients with viral etiology or with no pathogen) were evaluated as clinically bacterial if they fulfilled one of the following criteria: unilobar or multilobar pulmonary infiltrate on $\mathrm{CT}$ or CXR; C-reactive protein $(\mathrm{CRP})>100 \mathrm{mg} / \mathrm{l}$; procalcitonin $(\mathrm{PCT})>0.25 \mu \mathrm{g} / \mathrm{l}$; antibiotic therapy before rtPCR and with indeterminate biomarkers (CRP >100 mg/l and PCT $\leq 0.25 \mu \mathrm{g} / \mathrm{l}$ or CRP 51-100 mg/l and PCT not available). These criteria were adapted from earlier publications $[17,21]$ regarding the diagnosis of bacterial lower RTI.

The subgroup of patients with a viral etiology who had no clinically bacterial infection was considered to have a clinically viral infection. Children $(<18$ years) and adults ( $\geq 18$ years) were analyzed separately. Sepsis was defined according to standard criteria at the time [24]. Systemic inflammatory response syndrome (SIRS) criteria for children were defined as age-specific [25].

For the imaging, if patients had interstitial infiltrates or ground glass opacities in the absence of unilobar or multilobar infiltrates, only therapy against "atypical" pathogens (macrolide, quinolone, tetracycline; but not antibiotics for coverage of "typical" bacterial pathogens) was considered appropriate. If both CXR and CT were available, only CT readings were used for further analyses. An infiltrate was required for the diagnosis of pneumonia but no radiography was needed to diagnose a RTI in general.

\section{Laboratory procedures}

The multiplex rtPCR was performed according to the manufacturer's instruction (Seegene, Korea). The Anyplex $^{\text {Ts }}$ II RV16 detection kit (Seegene, Korea) detects the 
Table 1 Baseline characteristics for adult patients

\begin{tabular}{|c|c|c|c|c|c|c|c|}
\hline & \multirow{2}{*}{$\begin{array}{l}\text { Missing } \\
\text { values }\end{array}$} & \multirow{2}{*}{$\begin{array}{l}\text { Total } \\
(n=182)\end{array}$} & \multirow{2}{*}{$\begin{array}{l}\text { Viral }^{a} \\
(n=40)\end{array}$} & \multirow{2}{*}{$\begin{array}{l}\text { Any virus }{ }^{b} \\
(n=46)\end{array}$} & \multirow{2}{*}{$\begin{array}{l}\text { Other }^{c} \\
(n=142)\end{array}$} & \multicolumn{2}{|l|}{$p$-value ${ }^{d}$} \\
\hline & & & & & & $\begin{array}{l}\text { Viral vs. } \\
\text { any virus }\end{array}$ & $\begin{array}{l}\text { Viral vs. } \\
\text { other }\end{array}$ \\
\hline \multicolumn{8}{|l|}{ Demographics } \\
\hline $\begin{array}{l}\text { Age, mean years } \pm S D \\
\text { (range) }\end{array}$ & & $55.9 \pm 16.1(18-88)$ & $53.6 \pm 16.1(18-83)$ & $53.9 \pm 15.9(18-83)$ & $56.6 \pm 16.1(18-88)$ & 0.93 & 0.30 \\
\hline Female sex, n (\%) & & $76(41.8)$ & $14(35.0)$ & $19(41.3)$ & $62(43.7)$ & 0.55 & 0.33 \\
\hline Outpatients, n (\%) & & $20(11.0)$ & $5(12.5)$ & $5(10.9)$ & $15(10.6)$ & 1.00 & 0.92 \\
\hline \multicolumn{8}{|l|}{ Comorbidities, n (\%) } \\
\hline Asthma & & $13(7.1)$ & $2(5.0)$ & $4(8.7)$ & $11(7.7)$ & 0.81 & 0.85 \\
\hline COPD & & $27(10.6)$ & $5(12.5)$ & $7(15.2)$ & $22(15.5)$ & 0.72 & 0.64 \\
\hline Other chronic lung disease ${ }^{e}$ & & $26(14.3)$ & $2(5.0)$ & $2(4.3)$ & $24(16.9)$ & 1.00 & 0.06 \\
\hline Solid cancer ${ }^{f}$ & & $25(13.7)$ & $3(7.5)$ & $3(6.5)$ & $22(15.5)$ & 1.00 & 0.20 \\
\hline Hematologic malignancy & & $38(20.9)$ & $13(32.5)$ & $15(32.6)$ & $25(17.6)$ & 0.99 & 0.04 \\
\hline Organ transplantation & & $13(7.1)$ & $3(7.5)$ & $3(6.5)$ & $10(7.0)$ & 1.00 & 1.00 \\
\hline Neutropenia & & $20(11.0)$ & $9(22.5)$ & $9(19.6)$ & $11(7.7)$ & 0.74 & 0.03 \\
\hline HIV infection & & $6(3.3)$ & $1(2.5)$ & $2(4.3)$ & $5(3.5)$ & 1.00 & 1.00 \\
\hline Diabetes mellitus & & $27(14.8)$ & $6(15.0)$ & $7(15.2)$ & $21(14.8)$ & 0.98 & 0.97 \\
\hline $\begin{array}{l}\text { Collagen vascular disease/ } \\
\text { Vasculitis }\end{array}$ & & $33(18.1)$ & $4(10.0)$ & $5(10.9)$ & $29(20.4)$ & 1.00 & 0.13 \\
\hline Systemic steroids & & $49(26.9)$ & $11(27.5)$ & $14(30.4)$ & $38(26.8)$ & 0.77 & 0.93 \\
\hline Other Immunosuppression ${ }^{9}$ & & $21(11.5)$ & $5(12.5)$ & $6(13.0)$ & $16(11.3)$ & 0.94 & 1.00 \\
\hline Chronic renal failure & & $45(24.7)$ & $11(27.5)$ & $13(28.3)$ & $34(23.9)$ & 0.94 & 0.65 \\
\hline \multicolumn{8}{|l|}{ Clinical findings } \\
\hline $\begin{array}{l}\text { Systolic blood pressure, } \\
\text { mmHg, mean } \pm \text { SD (range) }\end{array}$ & 9 & $125 \pm 24(63-207)$ & $129 \pm 27(63-207)$ & $128 \pm 28(63-207)$ & $123 \pm 22(67-197)$ & 0.87 & 0.17 \\
\hline $\begin{array}{l}\text { Heart rate, beats } / \mathrm{min} \text {, } \\
\text { mean } \pm S D \text { (range) }\end{array}$ & 8 & $94 \pm 20(51-155)$ & $91 \pm 19(51-150)$ & $94 \pm 19(51-150)$ & $94 \pm 20(56-155)$ & 0.47 & 0.40 \\
\hline $\begin{array}{l}\text { Respiratory rate, breaths/min, } \\
\text { mean } \pm \text { SD (range) }\end{array}$ & 130 & $26 \pm 9(10-60)$ & $23 \pm 8(12-36)$ & $27 \pm 13(12-60)$ & $27 \pm 10(10-60)$ & 0.39 & 0.23 \\
\hline $\begin{array}{l}\text { Body temperature, }{ }^{\circ} \mathrm{C} \text {, } \\
\text { mean } \pm \mathrm{SD} \text { (range) }\end{array}$ & 20 & $37.6 \pm 1.0(35.4-42.0)$ & $37.5 \pm 0.9(35.6-39.6)$ & $37.5 \pm 0.9(35.6-39.6)$ & $37.6 \pm 1.0(35.4-42.0)$ & 1.00 & 0.59 \\
\hline \multicolumn{8}{|c|}{ Laboratory findings ${ }^{\mathrm{h}}$, mean \pm SD (range) } \\
\hline $\begin{array}{l}\text { C-reactive protein } \\
\text { (maximum), mg/l }\end{array}$ & 13 & $151 \pm 127(1-500)$ & $159 \pm 148(1-500)$ & $166 \pm 152(1-500)$ & $148 \pm 121(1-499)$ & 0.83 & 0.64 \\
\hline $\begin{array}{l}\text { White blood cells } \\
\text { (maximum), G/l }\end{array}$ & 11 & $11.5 \pm 10.2(0.0-97.0)$ & $12.2 \pm 16.8(1.8-97.0)$ & $12.6 \pm 16.3(1.8-97.0)$ & $11.3 \pm 7.3(0.0-41.1)$ & 0.91 & 0.75 \\
\hline Platelets (minimum), $\mathrm{G} / \mathrm{I}$ & 11 & $202 \pm 128(4-713)$ & $159 \pm 117(5-513)$ & $165 \pm 117(5-513)$ & $215 \pm 129(4-713)$ & 0.82 & 0.02 \\
\hline \multicolumn{8}{|l|}{ Discharge diagnosis, n (\%) } \\
\hline Bronchitis & & $22(12.1)$ & $7(17.5)$ & $7(15.2)$ & 15 (10.6) & 0.78 & 0.36 \\
\hline Acute exacerbation of COPD & & $5(2.7)$ & $1(2.5)$ & $1(2.2)$ & $4(2.8)$ & 1.00 & 1.00 \\
\hline $\begin{array}{l}\text { Upper respiratory tract } \\
\text { infection }\end{array}$ & & $8(4.4)$ & $4(10.0)$ & $4(8.7)$ & $4(2.8)$ & 1.00 & 0.14 \\
\hline $\begin{array}{l}\text { Respiratory tract infection, } \\
\text { unspecified }\end{array}$ & & $7(3.8)$ & $2(5.0)$ & $4(8.7)$ & $5(3.5)$ & 0.81 & 0.96 \\
\hline $\begin{array}{l}\text { Community-acquired } \\
\text { pneumonia }\end{array}$ & & $65(35.7)$ & $21(52.5)$ & $25(54.3)$ & $44(31.0)$ & 0.86 & 0.01 \\
\hline Hospital-acquired pneumonia & & $12(6.6)$ & $0(0.0)$ & $0(0.0)$ & $12(8.5)$ & $n / a$ & 0.09 \\
\hline
\end{tabular}


Table 1 Baseline characteristics for adult patients (Continued)

\begin{tabular}{|c|c|c|c|c|c|c|}
\hline Aspiration pneumonia & $1(0.5)$ & $0(0.0)$ & $0(0.0)$ & $1(0.7)$ & $n / a$ & 1.00 \\
\hline Tuberculosis & $3(1.6)$ & $0(0.0)$ & $0(0.0)$ & $3(2.1)$ & $n / a$ & 0.95 \\
\hline Other $^{i}$ & $59(32.4)$ & $5(12.5)$ & $5(10.9)$ & $54(38.0)$ & 1.00 & 0.002 \\
\hline
\end{tabular}

${ }^{\circ} \mathrm{C}$, degree Celsius, COPD chronic obstructive pulmonary disease, HIV human immunodeficiency virus, $n$ number, $S D$ standard deviation

${ }^{\mathrm{a}}$ Cases in which only one or more respiratory viruses were detected

${ }^{\mathrm{b}}$ Cases in which one or more respiratory viruses were detected (as single or mixed infection)

Includes bacterial etiology, mixed etiology, no pathogen

${ }^{\mathrm{d}}$ For continuous variables, 2-sample independent t-test was used. For categorical variables, Mantel-Haenszel chi square or Fisher exact test were used

'Other chronic lung diseases, e.g. cystic fibrosis, pulmonary sarcoidosis, pulmonary hypertension

fAll solid tumors including bronchial carcinoma

${ }^{9}$ Patients with one of the following conditions: primary or secondary antibody deficiency, congenital immunodeficiency, immunosuppressive therapy other than steroids, severe malnutrition with cachexia

${ }^{\mathrm{h}} \mathrm{Highest/lowest}$ value within a time period of 3 days before and 3 days after date of rtPCR

'Other infections $(n=10)$; neoplastic diseases $(n=6)$; collagen vascular; other rheumatologic or autoimmune $(n=14)$; sarcoidosis $(n=3)$; non-infectious nonneoplastic pulmonary diseases $(n=23)$; cardiovascular diseases $(n=3)$

following viruses: adenovirus, influenza A virus, influenza $B$ virus, parainfluenza virus 1, parainfluenza virus 2 , parainfluenza virus 3 , parainfluenza virus 4 , rhinovirus A/B/C, RSV A, RSV B, bocavirus $1 / 2 / 3 / 4$, human metapneumovirus, coronavirus 229E, coronavirus NL63, coronavirus OC43, and enterovirus. Specimens that arrived before mid-morning from Monday to Friday were processed daily and results were provided by mid-afternoon. Specimens that arrived afterwards were processed on the following workday and reported by mid-afternoon. Dates of specimen collection and testing were available, but not date and time of reporting of results. For CRP, white blood cell count (WBC) and platelets, the most pathologic values within 3 days before and after rtPCR results were documented.

\section{Statistical analyses}

Quantitative variables are described as means \pm standard deviations or median and interquartile range (IQR), as appropriate. Qualitative variables are presented as absolute counts and relative percentages. $\mathrm{x}^{2}$-test or Fisher's exact test were used to compare proportions, as appropriate. For continuous variables, the 2-sample independent $\mathrm{t}$-test or the Mann-Whitney-U-test were used. $P$-values $\leq 0.05$ (2-sided) were considered statistically significant. Multivariate logistic regression was used to examine whether different predictors were associated with virus detection. Variables with a $p$-value $\leq 0.05$ in the univariate logistic regression were included. SPSS version 20.0 for Windows software, OpenEpi (www.openepi.com) and Microsoft Excel 2010 were used for statistical analyses.

\section{Results}

rtPCR for respiratory viruses was performed on 328 respiratory specimens, of which 74 samples were excluded due to insufficient clinical information or repeated testing of separate specimens for respiratory viruses in the same patient within 3 weeks. Data on 254 patients were analyzed, including 11 sputa, 47 nasopharyngeal swabs, 63 nasopharyngeal aspirates, 123 bronchoalveolar lavages, 9 tracheal aspirates and 1 pleural effusion.

\section{Clinical characteristics}

Baseline characteristics are presented in Tables 1, 2 and 3 . One hundred and seven patients (42\%) were female, and 72 were children (28\%). Mean age in the group with viral infections was lower than in the remaining patients ( 29 vs. 47 years; $p<0.001$ ) but the difference was not significant if children and adults were analyzed separately (children 4.3 vs. 5.7 years; $p=0.28$; adults 53.6 vs. 56.6 years; $p=0.31$ ). There were more patients with neutropenia, hematological malignancy or collagen vascular disease/vasculitis in the viral group $(p<0.001 ; p=0.04$; $p=0.01$ ). Diagnosis of bronchitis and upper RTI were more common in the viral group ( $p=0.02 ; p=0.004)$.

\section{Pathogen identification}

Any pathogen was identified in 140 patients (55\%), in 89 of 182 adults (49\%) and in 51 of 72 children (71\%). Among these patients, one or more respiratory virus was detected in 91 (65\%), one or more bacteria in $53(38 \%)$ and a mixed viral-bacterial infection in $11(8 \%)$ patients. 45 of 72 children (63\%) were infected with one or more respiratory viruses. Compared to children, viral detection in adults was less frequent $(25 \%, n=46 ; p<0.001)$. A single pathogen was identified in 99 patients (39\%); multiple pathogens were detected in 41 patients (16\%). Distribution of detected pathogens and the differences between children and adults are shown in Table 4, and Figs. 1, 2a and b.

\section{Antibiotic therapy}

Of the 254 patients in the cohort, $61(24 \%)$ received antibiotics before hospitalization, and 149 (59\%) of all in- and outpatients received antibiotics at the time of rtPCR testing. Of 80 patients with a viral etiology, 59 (74\%) received antibiotics at any time point, 28 of 40 children (70\%) and 
Table 2 Baseline characteristics for pediatric patients

\begin{tabular}{|c|c|c|c|c|c|c|c|}
\hline & \multirow{2}{*}{$\begin{array}{l}\text { Missing } \\
\text { values }\end{array}$} & \multirow{2}{*}{$\begin{array}{l}\text { Total } \\
(n=72)\end{array}$} & \multirow{2}{*}{$\begin{array}{l}\text { Viral }^{a} \\
(n=40)\end{array}$} & \multirow{2}{*}{$\begin{array}{l}\text { Any virus }^{b} \\
(n=45)\end{array}$} & \multirow{2}{*}{$\begin{array}{l}\text { Other }^{c} \\
(n=32)\end{array}$} & \multicolumn{2}{|l|}{$p$-value $e^{d}$} \\
\hline & & & & & & $\begin{array}{l}\text { Viral vs. } \\
\text { any virus }\end{array}$ & $\begin{array}{l}\text { Viral vs. } \\
\text { other }\end{array}$ \\
\hline \multicolumn{8}{|l|}{ Demographics } \\
\hline $\begin{array}{l}\text { Age, mean years } \pm S D \\
\text { (range) }\end{array}$ & & $4.9 \pm 5.7(0-17)$ & $4.3 \pm 5.4(0-16)$ & $4.7 \pm 5.5(0-16)$ & $5.7 \pm 6.0(0-17)$ & 0.74 & 0.30 \\
\hline Female sex, n (\%) & & $31(43.1)$ & $14(35.0)$ & $18(40.0)$ & $17(53.1)$ & 0.64 & 0.13 \\
\hline Outpatients, n (\%) & & $3(4.2)$ & $2(5.0)$ & $2(4.4)$ & $1(3.1)$ & 1.00 & 1.00 \\
\hline \multicolumn{8}{|l|}{ Comorbidities, n (\%) } \\
\hline Asthma & & $1(1.4)$ & $1(2.5)$ & $1(2.2)$ & $0(0.0)$ & 1.00 & 1.00 \\
\hline Other chronic lung disease $\mathrm{e}^{\mathrm{e}}$ & & $13(18.1)$ & $7(17.5)$ & $8(17.8)$ & $6(18.8)$ & 0.97 & 0.89 \\
\hline Solid cancer ${ }^{f}$ & & $1(1.4)$ & $0(0.0)$ & $0(0.0)$ & $1(3.1)$ & $n / a$ & 0.89 \\
\hline Haematologic malignancy & & $10(13.9)$ & $8(20.0)$ & $9(20.0)$ & $2(6.3)$ & 1.00 & 0.18 \\
\hline Organ transplantation & & $1(1.4)$ & $1(2.5)$ & $1(2.2)$ & $0(0.0)$ & 1.00 & 1.00 \\
\hline Neutropenia & & $9(12.5)$ & $8(20.0)$ & $8(17.8)$ & $1(3.1)$ & 0.79 & 0.06 \\
\hline Systemic steroids & & $8(11.1)$ & $5(12.5)$ & $6(13.3)$ & $3(9.4)$ & 0.91 & 0.98 \\
\hline Other Immunosuppression ${ }^{9}$ & & $3(4.2)$ & $3(7.5)$ & $3(6.7)$ & $0(0.0)$ & 1.00 & 0.33 \\
\hline \multicolumn{8}{|l|}{ Clinical findings } \\
\hline $\begin{array}{l}\text { Systolic blood pressure, } \\
\mathrm{mmHg} \text {, mean } \pm \text { SD (range) }\end{array}$ & 29 & $100 \pm 18(59-140)$ & $106 \pm 15(71-140)$ & $105 \pm 14(71-140)$ & $95 \pm 18(59-120)$ & 0.82 & 0.04 \\
\hline $\begin{array}{l}\text { Heart rate, beats } / \mathrm{min} \text {, } \\
\text { mean } \pm \text { SD (range) }\end{array}$ & 3 & $136 \pm 33(60-234)$ & $138 \pm 32(60-186)$ & $134 \pm 32(60-186)$ & $135 \pm 35(72-234)$ & 0.58 & 0.71 \\
\hline $\begin{array}{l}\text { Respiratory rate, breaths/min, } \\
\text { mean } \pm \mathrm{SD} \text { (range) }\end{array}$ & 15 & $41 \pm 20(16-103)$ & $41 \pm 21(18-103)$ & $40 \pm 21(16-103)$ & $40 \pm 19(16-88)$ & 0.84 & 0.86 \\
\hline $\begin{array}{l}\text { Body temperature, }{ }^{\circ} \mathrm{C} \text {, } \\
\text { mean } \pm \mathrm{SD} \text { (range) }\end{array}$ & 3 & $37.6 \pm 1.1(35.0-40.1)$ & $37.5 \pm 1.1(35.0-39.5)$ & $37.5 \pm 1.1(35.0-39.5)$ & $37.7 \pm 1.1(35.1-40.1)$ & 1.00 & 0.46 \\
\hline \multicolumn{8}{|c|}{ Laboratory findings $s^{h}$, mean \pm SD (range) } \\
\hline $\begin{array}{l}\text { C-reactive protein } \\
\text { (maximum), mg/l }\end{array}$ & 2 & $85 \pm 141(5-999)$ & $62 \pm 77(5-291)$ & $67 \pm 81(5-293)$ & $113 \pm 191$ (7-999) & 0.78 & 0.16 \\
\hline $\begin{array}{l}\text { White blood cells } \\
\text { (maximum), G/l }\end{array}$ & 2 & $16.0 \pm 12.1(0.2-63.1)$ & $12.6 \pm 10.0(0.2-57.0)$ & $13.6 \pm 11.3(0.2-57.0)$ & $20.1 \pm 13.3(1.8-63.1)$ & 0.68 & 0.01 \\
\hline Platelets (minimum), G/I & 2 & $246 \pm 144(15-674)$ & $257 \pm 175(15-674)$ & $244 \pm 169(15-674)$ & $234 \pm 96(16-488)$ & 0.73 & 0.49 \\
\hline \multicolumn{8}{|l|}{ Discharge diagnosis, n (\%) } \\
\hline Bronchitis & & $10(13.9)$ & $9(22.5)$ & $9(20.0)$ & $1(3.1)$ & 0.78 & 0.04 \\
\hline $\begin{array}{l}\text { Upper respiratory tract } \\
\text { infection }\end{array}$ & & $14(19.4)$ & $9(22.5)$ & $10(22.2)$ & $5(15.6)$ & 0.98 & 0.47 \\
\hline $\begin{array}{l}\text { Respiratory tract infection, } \\
\text { unspecified }\end{array}$ & & $4(5.6)$ & $4(10.0)$ & $4(8.9)$ & $0(0.0)$ & 1.00 & 0.18 \\
\hline $\begin{array}{l}\text { Community-acquired } \\
\text { pneumonia }\end{array}$ & & $15(20.8)$ & $6(15.0)$ & $8(17.8)$ & $9(28.1)$ & 0.73 & 0.18 \\
\hline Hospital-acquired pneumonia & & $10(13.9)$ & $5(12.5)$ & $6(13.3)$ & $5(15.6)$ & 0.91 & 0.96 \\
\hline Aspiration pneumonia & & $2(2.8)$ & $1(2.5)$ & $2(4.4)$ & $1(3.1)$ & 1.00 & 1.00 \\
\hline Other' & & $17(23.6)$ & $6(15.0)$ & $6(13.3)$ & $11(34.4)$ & 0.83 & 0.06 \\
\hline
\end{tabular}

${ }^{\circ} \mathrm{C}$, degree Celsius, COPD chronic obstructive pulmonary disease, HIV human immunodeficiency virus, $n$ number, $S D$ standard deviation ${ }^{a}$ Cases in which only one or more respiratory viruses were detected

${ }^{\mathrm{b}}$ Cases in which one or more respiratory viruses were detected (as single or mixed infection)

Includes bacterial etiology, mixed etiology, no pathogen

${ }^{d}$ For continuous variables, 2-sample independent t-test was used. For categorical variables, Mantel-Haenszel chi square or Fisher exact test were used

'Other chronic lung diseases, e.g. cystic fibrosis, pulmonary sarcoidosis, pulmonary hypertension

${ }^{\mathrm{f}}$ All solid tumors including bronchial carcinoma

${ }^{9}$ Patients with one of the following conditions: primary or secondary antibody deficiency, congenital immunodeficiency, immunosuppressive therapy other than steroids, severe malnutrition with cachexia

${ }^{h}$ Highest/lowest value within a time period of 3 days before and 3 days after date of rtPCR

'Other infections ( $n=14)$; neoplastic diseases $(n=1)$; collagen vascular; other rheumatologic or autoimmune $(n=1)$; gastroesophageal diseases $(n=1)$ 
Table 3 Baseline characteristics for all patients

\begin{tabular}{|c|c|c|c|c|c|c|c|}
\hline & \multirow{2}{*}{$\begin{array}{l}\text { Missing } \\
\text { values }\end{array}$} & \multirow{2}{*}{$\begin{array}{l}\text { Total } \\
(n=254)\end{array}$} & \multirow{2}{*}{$\begin{array}{l}\text { Viral }^{a} \\
(n=80)\end{array}$} & \multirow{2}{*}{$\begin{array}{l}\text { Any virus }^{b} \\
(n=91)\end{array}$} & \multirow{2}{*}{$\begin{array}{l}\text { Other } \\
(n=174)\end{array}$} & \multicolumn{2}{|l|}{$p$-value $e^{d}$} \\
\hline & & & & & & $\begin{array}{l}\text { Viral vs. } \\
\text { any virus }\end{array}$ & $\begin{array}{l}\text { Viral vs. } \\
\text { other }\end{array}$ \\
\hline \multicolumn{8}{|l|}{ Demographics } \\
\hline Age, mean years $\pm S D$ (range) & & $41.5 \pm 26.9(0-88)$ & $29.0 \pm 27.5(0-83)$ & $29.6 \pm 27.4(0-83)$ & $47.2 \pm 24.7(0-88)$ & 0.89 & $<0.001$ \\
\hline Female sex, n (\%) & & $107(42.1)$ & $28(35.0)$ & $37(40.7)$ & $79(45.4)$ & 0.45 & 0.12 \\
\hline Children, $n(\%)$ & & $72(28.3)$ & $40(50.0)$ & $45(49.5)$ & $32(18.4)$ & 0.94 & $<0.001$ \\
\hline Outpatients, n (\%) & & $23(9.1)$ & $7(8.8)$ & $7(7.7)$ & $16(9.2)$ & 0.80 & 0.91 \\
\hline \multicolumn{8}{|l|}{ Comorbidities, n (\%) } \\
\hline Asthma & & $14(5.5)$ & $3(3.8)$ & $5(5.5)$ & $11(6.3)$ & 0.87 & 0.61 \\
\hline COPD & & $27(10.6)$ & $5(6.3)$ & $7(7.7)$ & $22(12.6)$ & 0.71 & 0.13 \\
\hline Other chronic lung disease $e^{e}$ & & $39(15.4)$ & $9(11.3)$ & $10(11.0)$ & $30(17.2)$ & 0.96 & 0.22 \\
\hline Solid cancer ${ }^{f}$ & & $26(10.2)$ & $3(3.8)$ & $3(3.3)$ & $23(13.2)$ & 1.00 & 0.02 \\
\hline Haematologic malignancy & & $48(18.9)$ & $21(26.3)$ & $24(26.4)$ & $27(15.5)$ & 0.99 & 0.04 \\
\hline Organ transplantation & & $14(5.5)$ & $4(5.0)$ & $4(4.4)$ & $10(5.7)$ & 1.00 & 1.00 \\
\hline Neutropenia & & $29(11.4)$ & $17(21.3)$ & $17(18.7)$ & $12(6.9)$ & 0.68 & $<0.001$ \\
\hline HIV infection & & $6(2.4)$ & $1(1.3)$ & $2(2.2)$ & $5(2.9)$ & 1.00 & 0.77 \\
\hline Diabetes mellitus & & $27(10.6)$ & $6(7.5)$ & $7(7.7)$ & $21(12.1)$ & 0.96 & 0.28 \\
\hline Collagen vascular disease/Nasculitis & & $33(13.0)$ & $4(5.0)$ & $5(5.5)$ & $29(16.7)$ & 1.00 & 0.01 \\
\hline Systemic steroids & & $57(22.4)$ & $16(20.0)$ & $20(22.0)$ & $41(23.6)$ & 0.75 & 0.53 \\
\hline Other Immunosuppression ${ }^{9}$ & & $24(9.4)$ & $8(10.0)$ & $9(9.9)$ & $16(9.2)$ & 0.98 & 0.84 \\
\hline Chronic renal failure & & $45(17.7)$ & $11(13.8)$ & $13(14.3)$ & $34(19.5)$ & 0.92 & 0.26 \\
\hline \multicolumn{8}{|l|}{ Clinical findings } \\
\hline $\begin{array}{l}\text { Systolic blood pressure, } \\
\mathrm{mmHg} \text {, mean } \pm \mathrm{SD} \text { (range) }\end{array}$ & 38 & $120 \pm 25(59-207)$ & $121 \pm 26(63-207)$ & $119 \pm 26(63-207)$ & $119 \pm 24(59-197)$ & 0.67 & 0.60 \\
\hline $\begin{array}{l}\text { Heart rate, beats } / \text { min, } \\
\text { mean } \pm S D \text { (range) }\end{array}$ & 11 & $106 \pm 31(51-234)$ & $114 \pm 35(51-186)$ & $114 \pm 33(51-186)$ & $102 \pm 28(56-234)$ & 1.00 & 0.01 \\
\hline $\begin{array}{l}\text { Respiratory rate, breaths/min, } \\
\text { mean } \pm \text { SD (range) }\end{array}$ & 145 & $34 \pm 18(10-103)$ & $37 \pm 21(12-103)$ & $37 \pm 20(12-103)$ & $32 \pm 15(10-88)$ & 1.00 & 0.17 \\
\hline $\begin{array}{l}\text { Body temperature, }{ }^{\circ} \mathrm{C} \text {, } \\
\text { mean } \pm \mathrm{SD} \text { (range) }\end{array}$ & 23 & $37.6 \pm 1.0(35.0-42.0)$ & $37.5 \pm 1.0(35.0-39.6)$ & $37.5 \pm 1.0(35.0-39.6)$ & $37.6 \pm 1.0(35.1-42.0)$ & 1.00 & 0.48 \\
\hline \multicolumn{8}{|l|}{ Laboratory findings ${ }^{h}$, mean $\pm S D$ (range) } \\
\hline $\begin{array}{l}\text { C-reactive protein } \\
\text { (maximum), mg/l }\end{array}$ & 15 & $132 \pm 134(1-999)$ & $111 \pm 127(1-500)$ & $117 \pm 132(1-500)$ & $141 \pm 137(1-999)$ & 0.77 & 0.11 \\
\hline $\begin{array}{l}\text { White blood cells } \\
\text { (maximum), G/l }\end{array}$ & 13 & $12.8 \pm 11.0(0.0-97.0)$ & $12.4 \pm 13.8(0.2-97.0)$ & $13.1 \pm 14.0(0.2-97.0)$ & $13.1 \pm 9.4(0.0-63.1)$ & 0.75 & 0.69 \\
\hline Platelets (minimum), G/l & 13 & $215 \pm 134(4-713)$ & $208 \pm 156(5-674)$ & $204 \pm 149(5-674)$ & $218 \pm 123(4-713)$ & 0.87 & 0.62 \\
\hline \multicolumn{8}{|l|}{ Discharge diagnosis, n (\%) } \\
\hline Bronchitis & & $32(12.6)$ & $16(20.0)$ & $16(17.6)$ & $16(9.2)$ & 0.69 & 0.02 \\
\hline Acute exacerbation of COPD & & $5(2.0)$ & $1(1.3)$ & $1(1.1)$ & $4(2.3)$ & 1.00 & 0.99 \\
\hline $\begin{array}{l}\text { Upper respiratory tract } \\
\text { infection }\end{array}$ & & $22(8.7)$ & $13(16.3)$ & $14(15.4)$ & $9(5.2)$ & 0.88 & 0.004 \\
\hline $\begin{array}{l}\text { Respiratory tract infection, } \\
\text { unspecified }\end{array}$ & & $11(4.3)$ & $6(7.5)$ & $8(8.8)$ & $5(2.9)$ & 0.76 & 0.18 \\
\hline $\begin{array}{l}\text { Community-acquired } \\
\text { pneumonia }\end{array}$ & & $80(31.5)$ & $27(33.8)$ & $33(36.3)$ & $53(30.5)$ & 0.73 & 0.60 \\
\hline Hospital-acquired pneumonia & & $22(8.7)$ & $5(6.3)$ & $6(6.6)$ & $17(9.8)$ & 0.93 & 0.36 \\
\hline Aspiration pneumonia & & $3(1.2)$ & $1(1.3)$ & $2(2.2)$ & $2(1.1)$ & 1.00 & 1.00 \\
\hline
\end{tabular}


Table 3 Baseline characteristics for all patients (Continued)

\begin{tabular}{lllll}
\hline Tuberculosis & $3(1.2)$ & $0(0.0)$ & $0(0.0)$ & $3(1.7)$ \\
Other $^{i}$ & $76(29.9)$ & $11(13.8)$ & $11(12.1)$ & 0.64 \\
\hline
\end{tabular}

${ }^{\circ} \mathrm{C}$, degree Celsius, COPD chronic obstructive pulmonary disease, HIV human immunodeficiency virus, $n$ number, $S D$ standard deviation

${ }^{a}$ Cases in which only one or more respiratory viruses were detected

${ }^{b}$ Cases in which one or more respiratory viruses were detected (as single or mixed infection)

cIncludes bacterial etiology, mixed etiology, no pathogen

${ }^{d}$ For continuous variables, 2-sample independent t-test was used. For categorical variables, Mantel-Haenszel chi square or Fisher exact test were used

e Other chronic lung diseases, e.g. cystic fibrosis, pulmonary sarcoidosis, pulmonary hypertension

${ }^{f}$ All solid tumors including bronchial carcinoma

${ }^{9}$ Patients with one of the following conditions: primary or secondary antibody deficiency, congenital immunodeficiency, immunosuppressive therapy other than steroids, severe malnutrition with cachexia

${ }^{\mathrm{h}}$ Highest/lowest value within a time period of 3 days before and 3 days after date of rtPCR

'Other infections ( $n=24)$; neoplastic diseases $(n=7)$; collagen vascular; other rheumatologic or autoimmune $(n=15)$; sarcoidosis $(n=3)$; non-infectious non-

neoplastic pulmonary diseases $(n=23)$; cardiovascular diseases $(n=3)$; gastroesophageal diseases $(n=1)$

Table 4 Relevant pathogens identified from respiratory specimens

\begin{tabular}{|c|c|c|c|}
\hline & Total $(n=254)$ & Adults $(n=182)$ & Children $(n=72)$ \\
\hline Bacteria, n (\%) & $66(26.0)$ & $54(29.7)$ & $12(16.7)$ \\
\hline Haemophilus influenzae & $12(4.7)$ & $11(6.0)$ & $1(1.4)$ \\
\hline Klebsiella pneumoniae & $8(3.1)$ & $6(3.3)$ & $2(2.8)$ \\
\hline Staphylococcus aureus & $4(1.6)$ & $1(0.5)$ & $3(4.2)$ \\
\hline Escherichia coli & $4(1.6)$ & $3(1.6)$ & $1(1.4)$ \\
\hline Pseudomonas aeruginosa & $4(1.6)$ & $4(2.2)$ & $0(0.0)$ \\
\hline Streptococcus pneumoniae & $3(1.2)$ & $2(1.1)$ & $1(1.4)$ \\
\hline Streptococcus pyogenes & $3(1.2)$ & $2(1.1)$ & $1(1.4)$ \\
\hline Legionella pneumophila & $3(1.2)$ & $3(1.6)$ & $0(0.0)$ \\
\hline Mycobacterium tuberculosis & $3(1.2)$ & $3(1.6)$ & $0(0.0)$ \\
\hline Mycoplasma pneumoniae & $1(0.4)$ & $0(0.0)$ & $1(1.4)$ \\
\hline Other bacteria & $21(8.3)$ & $19(10.4)$ & $2(2.8)$ \\
\hline Viruses, n (\%) & $119(46.9)$ & $54(29.7)$ & $65(90.3)$ \\
\hline Rhinovirus $\mathrm{A} / \mathrm{B} / \mathrm{C}$ & $33(13.0)$ & $16(8.8)$ & $17(23.6)$ \\
\hline Influenza A virus & $17(6.7)$ & $11(6.0)$ & $6(8.3)$ \\
\hline Influenza B virus & $4(1.6)$ & $0(0.0)$ & $4(5.6)$ \\
\hline Adenovirus & $14(5.5)$ & $4(2.2)$ & $10(13.9)$ \\
\hline Bocavirus 1/2/3/4 & $9(3.5)$ & $0(0.0)$ & $9(12.5)$ \\
\hline Respiratory syncytial virus A & $8(3.1)$ & $4(2.2)$ & $4(5.6)$ \\
\hline Respiratory syncytial virus B & $6(2.4)$ & $5(2.7)$ & $1(1.4)$ \\
\hline Parainfluenza virus 1 & $1(0.4)$ & $1(0.5)$ & $0(0.0)$ \\
\hline Parainfluenza virus 2 & $1(0.4)$ & $0(0.0)$ & $1(1.4)$ \\
\hline Parainfluenza virus 3 & $6(2.4)$ & $3(1.6)$ & $3(4.2)$ \\
\hline Parainfluenza virus 4 & $5(2.0)$ & $2(1.1)$ & $3(4.2)$ \\
\hline Human Metapneumovirus & $5(2.0)$ & $2(1.1)$ & $3(4.2)$ \\
\hline Enterovirus & $3(1.2)$ & $0(0.0)$ & $3(4.2)$ \\
\hline Coronavirus 229E & $1(0.4)$ & $1(0.5)$ & $0(0.0)$ \\
\hline Coronavirus NL63 & $2(0.8)$ & $1(0.5)$ & $1(1.4)$ \\
\hline Coronavirus OC43 & $1(0.4)$ & $1(0.5)$ & $0(0.0)$ \\
\hline Non respiratory viruses & $3(1.2)$ & $3(1.6)$ & $0(0.0)$ \\
\hline Fungi, n (\%) & $10(3.9)$ & $9(4.9)$ & $1(1.4)$ \\
\hline Pneumocystis jirovecii & $6(2.4)$ & $6(3.3)$ & $0(0.0)$ \\
\hline Other fungi & $4(1.6)$ & $3(1.6)$ & $1(1.4)$ \\
\hline
\end{tabular}

Pathogens associated with mixed infections were counted individually 


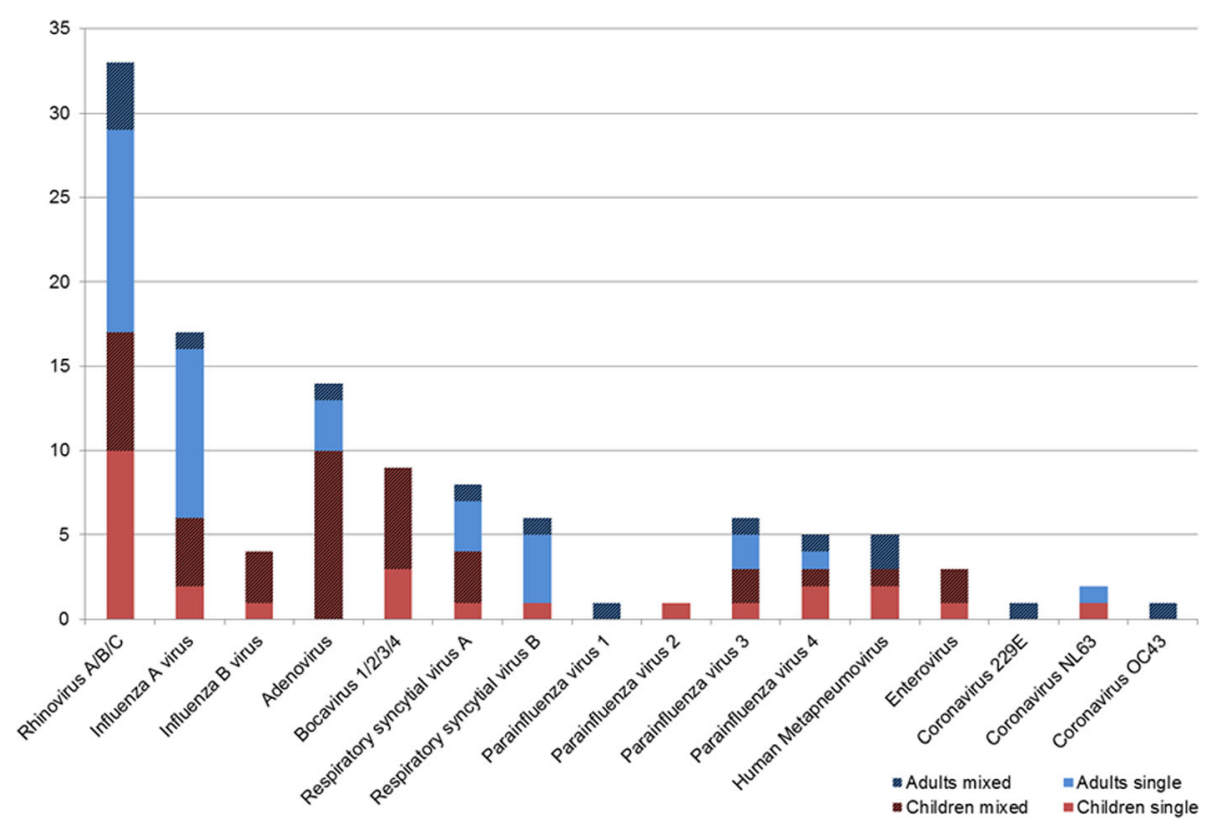

Fig. 1 Distribution of respiratory viruses detected as single or mixed pathogen

31 of 40 adults (78\%). Inpatients with a bacterial etiology were treated with antibiotics in $92 \%(p=0.09)$ and longer than those with a viral etiology or no pathogen $(p=0.02$; $p=0.01)$. If children and adults were analyzed individually, similar but non-significant trends were observed (Tables 5 , 6 and 7).

\section{Influence of rtPCR testing on management}

The effect of rtPCR analysis on antibiotic management is presented in Tables 8, 9 and 10. After exclusion of patients who received antibiotics for other indications virus detection was temporally associated with discontinuation of antibiotics in 2 of 20 adults (10\%) and 6 of 14 children (43\%). In patients with viral etiology, management was more frequently judged correct in children $(18 / 27,67 \%)$ than in adults $(12 / 35,34 \% ; p=0.01)$ after rtPCR results became available. In adults, management of viral etiology was less often judged correct compared to adults with bacterial etiology $(p=0.002)$. Among patients with clinically viral etiology, children were more frequently managed correctly $(15 / 15,100 \%)$ than adults $(8 / 13,62 \%$; $p=0.03$ ).

Eight adults and one child received oseltamivir. In four of five patients with proven influenza A virus infection, the antiviral medication was prescribed in response to the positive rtPCR analysis. In another child, oseltamivir was commenced after the third successive detection of influenza A virus within a month and stopped after 1 day. In two other patients, antiviral therapy was started or continued despite an rtPCR analysis negative for influenza and positive for other respiratory viruses. In another patient with identification of only bacterial
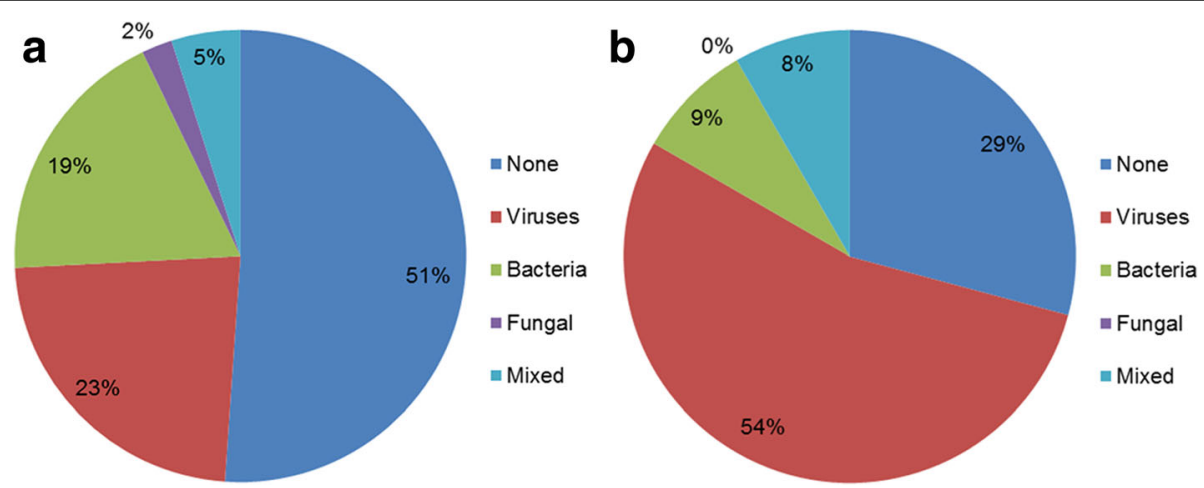

Fig. 2 a Distribution of identified pathogens for adults. b Distribution of identified pathogens for children 
Table 5 Outcome depending on relevant detected pathogen for adult patients

\begin{tabular}{|c|c|c|c|c|c|c|c|}
\hline & \multirow{2}{*}{$\begin{array}{l}\text { Viral } \\
(n=40)\end{array}$} & \multirow{2}{*}{$\begin{array}{l}\text { Bacterial } \\
(n=36)\end{array}$} & \multirow{2}{*}{$\begin{array}{l}\text { Mixed } \\
(n=6)\end{array}$} & \multirow{2}{*}{$\begin{array}{l}\text { No pathogen } \\
(n=100)\end{array}$} & \multicolumn{3}{|l|}{$p$-value ${ }^{a}$} \\
\hline & & & & & $\begin{array}{l}\text { Viral vs. } \\
\text { bacterial }\end{array}$ & $\begin{array}{l}\text { Viral vs. } \\
\text { mixed }\end{array}$ & $\begin{array}{l}\text { Viral vs. no } \\
\text { pathogen }\end{array}$ \\
\hline LOS inpatients, median days (IQR) & $8(6-21)$ & $21(13-35)$ & $11.5(5-44.25)$ & $15(8-23.5)$ & $<0.001$ & 0.67 & 0.03 \\
\hline \multicolumn{8}{|l|}{ Complications, n (\%) } \\
\hline ICU admission & $11(27.5)$ & $13(36.1)$ & $3(50.0)$ & $24(24.0)$ & 0.42 & 0.51 & 0.67 \\
\hline Mechanical ventilation & $6(15.0)$ & $11(30.6)$ & $3(50.0)$ & $19(19.0)$ & 0.11 & 0.16 & 0.58 \\
\hline ARDS & $3(7.5)$ & $5(13.9)$ & $2(33.3)$ & $6(6.0)$ & 0.60 & 0.24 & 1.00 \\
\hline Sepsis & $24(60.0)$ & $24(66.7)$ & $5(83.3)$ & $6(6.0)^{b}$ & 0.55 & 0.53 & $\mathrm{n} / \mathrm{a}$ \\
\hline Mortality (all cause) & $4(10.0)$ & $4(11.1)$ & $1(16.7)$ & $6(6.0)$ & 1.00 & 1.00 & 0.62 \\
\hline \multicolumn{8}{|l|}{ Antibiotic use (any indication) } \\
\hline Any inpatient antibiotics, n (\%) & $30 / 35(85.7)$ & 29/32 (90.6) & $4 / 6(66.7)$ & 72/89 (80.9) & 0.81 & 0.54 & 0.53 \\
\hline $\begin{array}{l}\text { Duration of inpatient use, } \\
\text { mean days } \pm S D \text { (range) }\end{array}$ & $12.5 \pm 14.3(0-63)$ & $18.1 \pm 16.0(0-72)$ & $10.3 \pm 12.1(0-31)$ & $10.8 \pm 11.4(0-63)$ & 0.14 & 0.73 & 0.49 \\
\hline $\begin{array}{l}\text { Discharged receiving oral } \\
\text { antibiotics, } n(\%)\end{array}$ & $11(30.6)^{c}$ & $17(53.1)^{d}$ & $1(20.0)^{\mathrm{e}}$ & $23(24.5)^{f}$ & 0.06 & 1.00 & 0.48 \\
\hline
\end{tabular}

$A R D S$ acute respiratory distress syndrome, ICU intensive care unit, IQR interquartile range, $L O S$ length of stay, $n$ number, $S D$ standard deviation

${ }^{\mathrm{a}}$ For continuous variables, 2-sample independent $\mathrm{t}$-test or Mann-Whitney-U-test were used. For categorical variables, Mantel-Haenszel chi square or Fisher exact test were used

${ }^{\mathrm{b}}$ Sepsis requires a pathogen per definition. In these six cases sepsis was exceptionally defined according to discharge papers

Missing values due to death or ongoing hospitalisation at time of analysis (number): $c 4 ; \mathrm{d} 4 ; \mathrm{e} 1$; f6. For calculation of percentage and $p$-value missing values were excluded

pathogens, oseltamivir was stopped after negative rtPCR results were available. In an additional case with detection of bacteria only, antiviral medication was started 3 days after rtPCR analysis and it was stopped again on the next day.

\section{Outcomes depending on etiology}

Hospital length of stay (LOS) was longer in patients with bacterial etiology compared to patients with a viral etiology. For children, LOS did not significantly vary in the different groups between viral and bacterial etiologies

Table 6 Outcome depending on relevant detected pathogen for pediatric patients

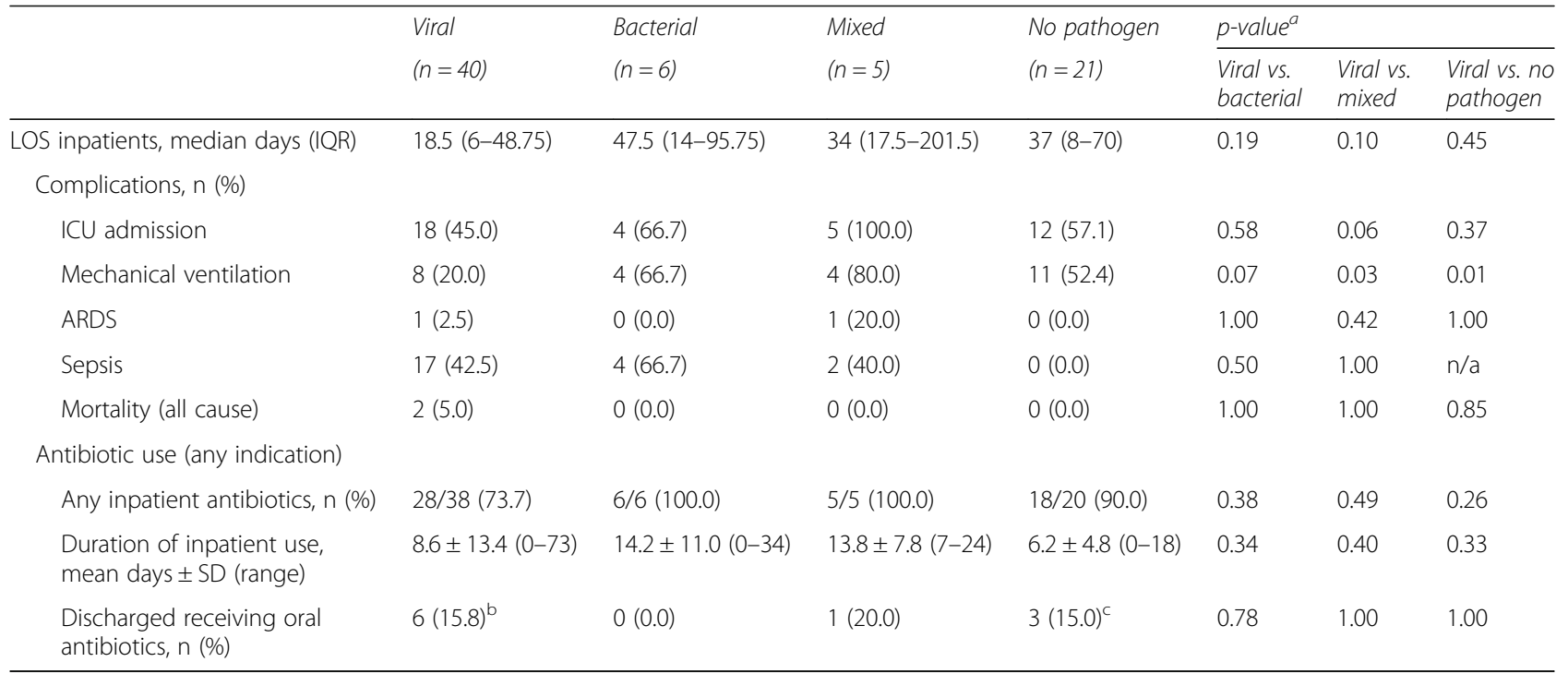

ARDS acute respiratory distress syndrome, $I C U$ intensive care unit, $I Q R$ interquartile range, $L O S$ length of stay, $n$ number, $S D$ standard deviation ${ }^{a}$ For continuous variables, 2-sample independent t-test or Mann-Whitney-U-test were used. For categorical variables, Mantel-Haenszel chi square or Fisher exact test were used

Missing values due to death or ongoing hospitalisation at time of analysis (number): b2; c1. For calculation of percentage and $p$-value missing values were excluded 
Table 7 Outcome depending on relevant detected pathogen for all patients

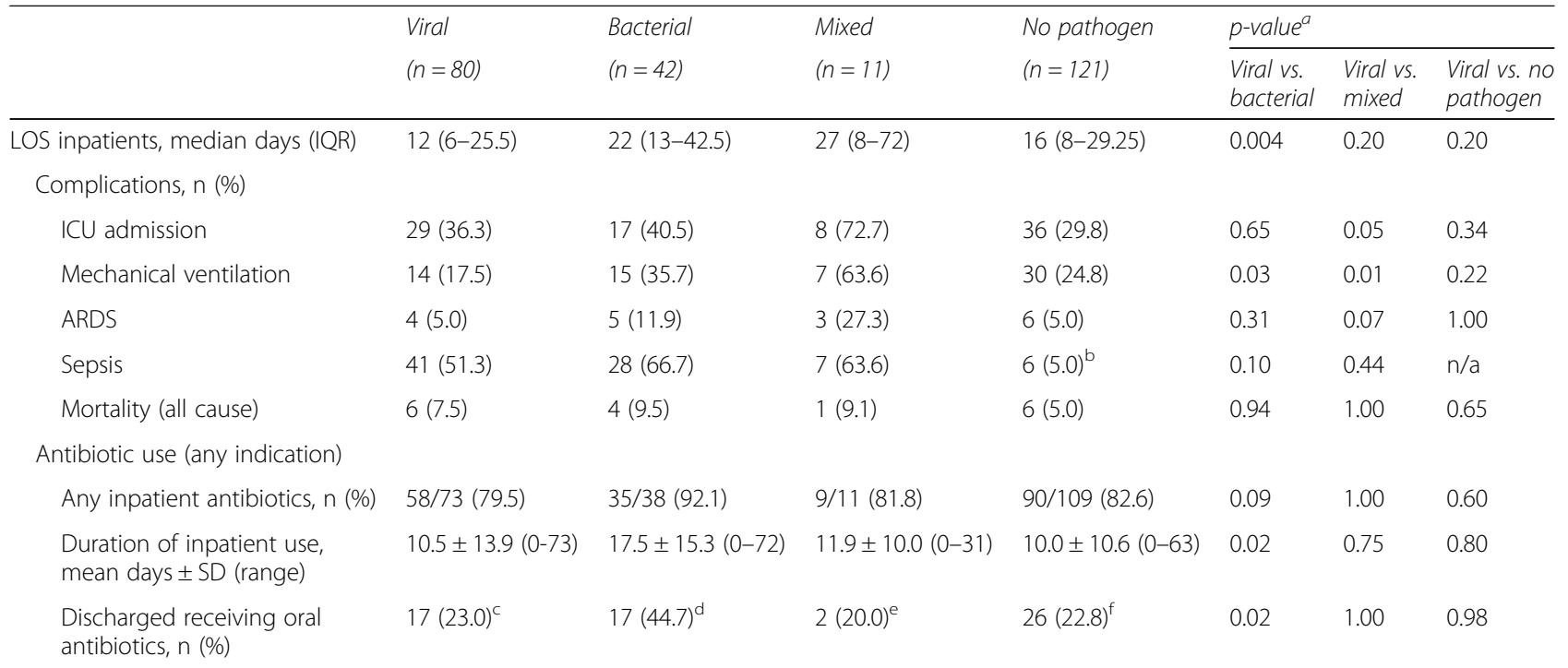

$A R D S$ acute respiratory distress syndrome, ICU intensive care unit, IQR interquartile range, $L O S$ length of stay, $n$ number, $S D$ standard deviation ${ }^{\mathrm{a}}$ For continuous variables, 2-sample independent $\mathrm{t}$-test or Mann-Whitney-U-test were used. For categorical variables, Mantel-Haenszel chi square or Fisher exact test were used

${ }^{\mathrm{b}}$ Sepsis requires a pathogen per definition. In these six cases sepsis was exceptionally defined according to discharge papers

Missing values due to death or ongoing hospitalisation at time of analysis (number): $c 6 ; \mathrm{d} 4$; e1; f7. For calculation of percentage and $p$-value missing values were excluded

(Tables 5, 6 and 7). Patients with a mixed infection were more frequently admitted to the intensive care unit (ICU) and mechanically ventilated compared to patients with a viral etiology ( $p=0.05 ; p=0.005$; respectively). If children and adults were analyzed separately, the differences within the adult population were not significant; in children, more patients with a mixed infection were mechanically ventilated $(p=0.03)$. All-cause and RTIassociated mortality was comparable between pathogen groups.
In patients with viral etiology there was no difference in mortality between those who discontinued antibiotics compared to those who did not $(1 / 8$ [13\%] vs. $3 / 26$ [12\%]; $p=1.00)$. LOS was shorter in inpatients who discontinued antibiotics (median days 5 [IQR 3-11.75] vs. 10.5 [IQR 6-19.25]; $p=0.05$ ). Patients in whom antibiotics were continued despite a viral detection were as frequently admitted to ICU $(11 / 26[42 \%]$ vs. $5 / 8[63 \%] ; p=0.55)$ or mechanically ventilated $(6 / 26[23 \%]$ vs. $1 / 8[13 \%] ; p=0.93)$ as patients in whom antibiotics were discontinued. The

Table 8 Change of antibiotic therapy after rtPCR, adult patients with another indication for antibiotics were excluded

\begin{tabular}{|c|c|c|c|c|c|c|c|c|c|}
\hline & Viral & Bacterial & Mixed & No pathogen & Clinically & Clinically & $p$-value & & \\
\hline & $(n=35)$ & $(n=33)$ & $(n=6)$ & $(n=84)$ & bacterial $^{a}(n=84)$ & $\operatorname{viral}^{\mathrm{b}}(n=13)$ & $\begin{array}{l}\text { Viral vs. } \\
\text { bacterial }\end{array}$ & $\begin{array}{l}\text { Viral vs. } \\
\text { mixed }\end{array}$ & $\begin{array}{l}\text { Viral vs. no } \\
\text { pathogen }\end{array}$ \\
\hline $\begin{array}{l}\text { No antibiotic treatment before } \\
\text { and after rtPCR, n (\%) }\end{array}$ & $10(28.6)$ & $7(21.2)$ & $2(33.3)$ & $32(38.1)$ & $18(21.4)$ & $8(61.5)$ & 0.49 & 1.00 & 0.32 \\
\hline $\begin{array}{l}\text { Antibiotic treatment stopped } \\
\text { after rtPCR, n (\%) }\end{array}$ & $2(5.7)$ & $2(6.1)$ & $0(0.0)$ & $2(2.4)$ & $4(4.8)$ & $0(0.0)$ & 1.00 & 1.00 & 0.67 \\
\hline $\begin{array}{l}\text { Antibiotic treatment started } \\
\text { after rtPCR, n (\%) }\end{array}$ & $5(14.3)$ & $4(12.1)$ & $2(33.3)$ & $8(9.5)$ & $7(8.3)$ & $3(23.1)$ & 1.00 & 0.54 & 0.64 \\
\hline $\begin{array}{l}\text { Antibiotic treatment before } \\
\text { and after rtPCR, n (\%) }\end{array}$ & $18(51.4)$ & $20(60.6)$ & $2(33.3)$ & $42(50.0)$ & $55(65.5)$ & $2(15.4)$ & 0.45 & 0.71 & 0.89 \\
\hline Correct management, n (\%) & $12(34.3)$ & $24(72.7)$ & $4(66.7)$ & & $62(73.8)$ & $8(61.5)$ & 0.002 & 0.30 & $\mathrm{n} / \mathrm{a}$ \\
\hline
\end{tabular}

$n$ number; rtPCR, real-time polymerase chain reaction

${ }^{a}$ Cases without detection of bacteria were evaluated as clinically bacterial if they fulfilled one of the following criteria: unilobular or multilobular pulmonary infiltrate or CRP $>100 \mathrm{mg} / \mathrm{l}$ or PCT $>0.25 \mu \mathrm{g} / \mathrm{l}$ or antibiotic therapy before rtPCR and no bacterium detection and biomarkers indeterminate (CRP $>100 \mathrm{mg} / \mathrm{l}$ and $\mathrm{PCT} \leq 0.25 \mu \mathrm{g} / \mathrm{l}$ or CRP between 51 and $100 \mathrm{mg} / \mathrm{l}$ and PCT not available)

${ }^{b}$ Cases with a detected viral pathogen excluding those patients with a clinically bacterial co-infection (as described above)

cMantel-Haenszel chi square test or Fisher exact test were used 
Table 9 Change of antibiotic therapy after rtPCR, pediatric patients with another indication for antibiotics were excluded

\begin{tabular}{|c|c|c|c|c|c|c|c|c|c|}
\hline & \multirow{2}{*}{$\begin{array}{l}\text { Viral } \\
(n=27)\end{array}$} & \multirow{2}{*}{$\begin{array}{l}\text { Bacterial } \\
(n=4)\end{array}$} & \multirow{2}{*}{$\begin{array}{l}\text { Mixed } \\
(n=3)\end{array}$} & \multirow{2}{*}{$\begin{array}{l}\text { No pathogen } \\
(n=18)\end{array}$} & \multirow{2}{*}{$\begin{array}{l}\text { Clinically } \\
\text { bacterial' }(n=22)\end{array}$} & \multirow{2}{*}{$\begin{array}{l}\text { Clinically } \\
\text { viral }^{b}(n=15)\end{array}$} & \multicolumn{3}{|l|}{$p$-value } \\
\hline & & & & & & & $\begin{array}{l}\text { Viral vs. } \\
\text { bacterial }\end{array}$ & $\begin{array}{l}\text { Viral vs. } \\
\text { mixed }\end{array}$ & $\begin{array}{l}\text { Viral vs. no } \\
\text { pathogen }\end{array}$ \\
\hline $\begin{array}{l}\text { No antibiotic treatment before } \\
\text { and after rtPCR, } n(\%)\end{array}$ & $12(44.4)$ & $1(25.0)$ & $0(0.0)$ & $6(33.3)$ & $6(27.3)$ & $11(73.3)$ & 0.87 & 0.40 & 0.46 \\
\hline $\begin{array}{l}\text { Antibiotic treatment stopped } \\
\text { after rtPCR, } \mathrm{n}(\%)\end{array}$ & $6(22.2)$ & $0(0.0)$ & $0(0.0)$ & $1(5.6)$ & $2(9.1)$ & $4(26.7)$ & 0.80 & 1.00 & 0.27 \\
\hline $\begin{array}{l}\text { Antibiotic treatment started } \\
\text { after rtPCR, } \mathrm{n}(\%)\end{array}$ & $1(3.7)$ & $0(0.0)$ & $1(33.3)$ & $3(16.7)$ & $3(13.6)$ & $0(0.0)$ & 1.00 & 0.39 & 0.34 \\
\hline $\begin{array}{l}\text { Antibiotic treatment before } \\
\text { and after } r \mathrm{tPCR}, \mathrm{n}(\%)\end{array}$ & $8(29.6)$ & $3(75.0)$ & $2(66.7)$ & $8(44.4)$ & $11(50.0)$ & $0(0.0)$ & 0.23 & 0.50 & 0.32 \\
\hline Correct management, $\mathrm{n}(\%)$ & $18(66.7)$ & $3(75.0)$ & $3(100.0)$ & & $14(63.6)$ & $15(100.0)$ & 1.00 & 0.66 & $\mathrm{n} / \mathrm{a}$ \\
\hline
\end{tabular}

$n$ number; rtPCR, real-time polymerase chain reaction

${ }^{a}$ Cases without detection of bacteria were evaluated as clinically bacterial if they fulfilled one of the following criteria: unilobular or multilobular pulmonary infiltrate or CRP $>100 \mathrm{mg} / \mathrm{l}$ or PCT $>0.25 \mu \mathrm{g} / \mathrm{l}$ or antibiotic therapy before rtPCR and no bacterium detection and biomarkers indeterminate (CRP $>100 \mathrm{mg} / \mathrm{l}$ and $\mathrm{PCT} \leq 0.25 \mu \mathrm{g} / \mathrm{l}$ or CRP between 51 and $100 \mathrm{mg} / \mathrm{l}$ and PCT not available)

${ }^{b}$ Cases with a detected viral pathogen excluding those patients with a clinically bacterial co-infection (as described above)

'Mantel-Haenszel chi square test or Fisher exact test were used

proportion of patients with sepsis was comparable $(16 / 26$ [62\%] vs. $6 / 8[75 \%] ; p=0.80)$. These results were similar if adults and children were analyzed separately.

\section{Radiological findings depending on etiology}

Normal CXR findings were significantly more frequent in patients with viral infection compared to bacterial infections (30\% vs. $9 \%$; $p=0.03)$. Multilobar infiltrates and pleural effusion on CXR were observed less often among subjects with viral infection (Tables 11, 12 and 13).

\section{Predictors of viral etiology}

In multivariate logistic regression (Tables 14 and 15), the absence of pleural effusion in adults was associated with detection of respiratory viruses (odds ratio [OR] 0.31, 95\% confidence interval $[\mathrm{CI}]$ 0.12-0.80). For children, the lack of multilobar infiltrates was a significant predictor of respiratory virus detection (OR 0.22, 95\% CI 0.06-0.81).

\section{Discussion}

There are three main findings in this retrospective cohort study of the impact of viral multiplex rtPCR. First, the majority of patients with viral RTI received antibiotics and antibiotics were discontinued after viral detection in only a minority of patients. Second, when biomarkers, radiologic presentations and antibiotic pretreatment were taken into account and categories of clinically bacterial and clinically viral infections were created (which more closely reflect clinical decision making), the multiplex rtPCR showed a greater impact and considerably improved correct management of clinically viral infections, from 67 to $100 \%$ among children and from 34 to $62 \%$ among adults. Third, the impact of rtPCR testing seemed to be more accentuated in

Table 10 Change of antibiotic therapy after rtPCR, all patients with another indication for antibiotics were excluded

\begin{tabular}{|c|c|c|c|c|c|c|c|c|c|}
\hline & & Bacterial & Mixed & No pathogen & Clinically & Clinically & $p$-value & & \\
\hline & $(n=62)$ & $(n=37)$ & $(n=9)$ & $(n=102)$ & bacterial $^{\mathrm{a}}(n=106)$ & viral $^{\mathrm{b}}(n=28)$ & $\begin{array}{l}\text { Viral vs. } \\
\text { bacterial }\end{array}$ & $\begin{array}{l}\text { Viral vs. } \\
\text { mixed }\end{array}$ & $\begin{array}{l}\text { Viral vs. no } \\
\text { pathogen }\end{array}$ \\
\hline $\begin{array}{l}\text { No antibiotic treatment before } \\
\text { and after rtPCR, n (\%) }\end{array}$ & $22(35.5)$ & $8(21.6)$ & $2(22.2)$ & $38(37.3)$ & $24(22.6)$ & $19(67.9)$ & 0.15 & 0.71 & 0.82 \\
\hline $\begin{array}{l}\text { Antibiotic treatment stopped } \\
\text { after rtPCR, n (\%) }\end{array}$ & $8(12.9)$ & $2(5.4)$ & $0(0.0)$ & $3(2.9)$ & $6(5.7)$ & $4(14.3)$ & 0.40 & 0.64 & 0.03 \\
\hline $\begin{array}{l}\text { Antibiotic treatment started } \\
\text { after rtPCR, n (\%) }\end{array}$ & $6(9.7)$ & $4(10.8)$ & $3(33.3)$ & $11(10.8)$ & $10(9.4)$ & $3(10.7)$ & 1.00 & 0.16 & 0.82 \\
\hline $\begin{array}{l}\text { Antibiotic treatment before } \\
\text { and after rtPCR, n (\%) }\end{array}$ & $26(41.9)$ & $23(62.2)$ & $4(44.4)$ & $50(49.0)$ & $66(62.3)$ & $2(7.1)$ & 0.05 & 1.00 & 0.38 \\
\hline Correct management, n (\%) & $30(48.4)$ & $27(73.0)$ & $7(77.7)$ & & $76(71.7)$ & $23(82.1)$ & 0.02 & 0.19 & $\mathrm{n} / \mathrm{a}$ \\
\hline
\end{tabular}

$n$ number; rtPCR, real-time polymerase chain reaction

${ }^{a}$ Cases without detection of bacteria were evaluated as clinically bacterial if they fulfilled one of the following criteria: unilobular or multilobular pulmonary infiltrate or CRP $>100 \mathrm{mg} / \mathrm{l}$ or PCT $>0.25 \mu \mathrm{g} / \mathrm{l}$ or antibiotic therapy before rtPCR and no bacterium detection and biomarkers indeterminate (CRP $>100 \mathrm{mg} / \mathrm{l}$ and $\mathrm{PCT} \leq 0.25 \mu \mathrm{g} / \mathrm{l}$ or CRP between 51 and $100 \mathrm{mg} / \mathrm{l}$ and PCT not available)

${ }^{b}$ Cases with a detected viral pathogen excluding those patients with a clinically bacterial co-infection (as described above)

cMantel-Haenszel chi square test or Fisher exact test were used 
Table 11 Radiological findings for adult patients

\begin{tabular}{|c|c|c|c|c|c|c|c|}
\hline & $\begin{array}{l}\text { Viral } \\
(n=40)\end{array}$ & $\begin{array}{l}\text { Bacterial } \\
(n=36)\end{array}$ & $\begin{array}{l}\text { Mixed } \\
(n=6)\end{array}$ & $\begin{array}{l}\text { No pathogen } \\
(n=100)\end{array}$ & Viral vs. bacterial & $\begin{array}{l}p \text {-value } \\
\text { Viral vs. mixed }\end{array}$ & Viral vs. no pathogen \\
\hline X-ray, (n) & 33 & 26 & 5 & 81 & & & \\
\hline Unilobar infiltrate, n (\%) & $9(27.3)$ & $5(19.2)$ & $0(0.0)$ & $14(17.3)$ & 0.48 & 0.47 & 0.23 \\
\hline Multilobar infiltrates, n (\%) & $6(18.2)$ & $10(38.5)$ & $2(40.0)$ & $30(37.0)$ & 0.09 & 0.56 & 0.05 \\
\hline Interstitial infiltrates, n (\%) & $3(9.1)$ & $7(26.9)$ & $1(20.0)$ & $17(21.0)$ & 0.14 & 0.89 & 0.13 \\
\hline Pleural effusion, n (\%) & $5(15.2)$ & $11(42.3)$ & $0(0.0)$ & $24(29.6)$ & 0.02 & 0.95 & 0.11 \\
\hline Normal, n (\%) & $8(24.2)$ & $2(7.7)$ & $1(20.0)$ & $14(17.3)$ & 0.18 & 1.00 & 0.40 \\
\hline Computer tomography, (n) & 23 & 29 & 5 & 71 & & & \\
\hline Unilobar infiltrate, n (\%) & $5(21.7)$ & $4(13.8)$ & $0(0.0)$ & $7(9.9)$ & 0.70 & 0.69 & 0.26 \\
\hline Multilobar infiltrates, n (\%) & $11(47.8)$ & $16(55.2)$ & $4(80.0)$ & $32(45.1)$ & 0.60 & 0.42 & 0.82 \\
\hline Ground glass opacity, n (\%) & $4(17.4)$ & $6(20.7)$ & $2(40.0)$ & $29(40.8)$ & 1.00 & 0.57 & 0.04 \\
\hline Pleural effusion, n (\%) & $5(21.7)$ & $13(44.8)$ & $1(20.0)$ & $25(35.2)$ & 0.09 & 1.00 & 0.23 \\
\hline Normal, n (\%) & $2(8.7)$ & $0(0.0)$ & $0(0.0)$ & $0(0.0)$ & 0.38 & 1.00 & 0.12 \\
\hline
\end{tabular}

$n$ number. Multiple findings were counted individually

${ }^{a}$ Mantel-Haenszel chi square test or Fisher exact test were used

children than in adults. More children than adults had an appropriate discontinuation of antibiotics, and the overall management of viral infections was superior in children compared to adults. Importantly, but with the caveat of small numbers, there was no evidence that outcome was worse in those with viral etiology who discontinued antibiotics compared to those who did not.

Several previous studies analyzed the impact of rapid availability of rtPCR results on antibiotic use. In a randomized controlled trial (RCT) of 107 adults with lower RTI, antibiotics were partially or totally discontinued in $6(11 \%)$ of 55 patients for whom rtPCR results were available, albeit without overall reduction in antibiotic treatment duration [7]. In a controlled clinical trial enrolling 583 children with acute RTI, Wishaupt et al. [4] evaluated the diagnostic yield and effect of rapid communication of rtPCR results (within 12-36 h vs. 4 weeks after testing) and failed to show a significant influence on the duration of antibiotic treatment. In contrast, Brittain-Long et al. [20] demonstrated in a RCT with 406 adults that patients randomized to rapid rtPCR results received antibiotics less frequently for acute RTI in a primary care setting during their initial visit $(4.5 \%$ vs. $12.3 \% ; p=0.01)$. However, at the 10-day follow-up the prescription rates were similar again $(13.9 \%$ vs. $17.2 \%$; $p=0.36)$ [20]. Contrary to these findings, a retrospective pre-post study of

Table 12 Radiological findings for pediatric patients

\begin{tabular}{|c|c|c|c|c|c|c|c|}
\hline & $\begin{array}{l}\text { Viral } \\
(n=40)\end{array}$ & $\begin{array}{l}\text { Bacterial } \\
(n=6)\end{array}$ & $\begin{array}{l}\text { Mixed } \\
(n=5)\end{array}$ & $\begin{array}{l}\text { No pathogen } \\
(n=21)\end{array}$ & Viral vs. bacterial & $\begin{array}{l}p \text {-value } \\
\text { Viral vs. mixed }\end{array}$ & Viral vs. no pathogen \\
\hline X-ray, (n) & 28 & 6 & 5 & 16 & & & \\
\hline Unilobar infiltrate, n (\%) & $6(21.4)$ & $0(0.0)$ & $1(20.0)$ & $2(12.5)$ & 0.56 & 1.00 & 0.76 \\
\hline Multilobar infiltrates, n (\%) & $6(21.4)$ & $2(33.3)$ & $4(80.0)$ & $6(37.5)$ & 0.88 & 0.04 & 0.42 \\
\hline Interstitial infiltrates, n (\%) & $2(7.1)$ & $1(16.7)$ & $1(20.0)$ & $2(12.5)$ & 0.91 & 0.80 & 0.93 \\
\hline Pleural effusion, n (\%) & $4(14.3)$ & $2(33.3)$ & $1(20.0)$ & $2(12.5)$ & 0.56 & 1.00 & 1.00 \\
\hline Normal, n (\%) & $10(35.7)$ & $1(16.7)$ & $0(0.0)$ & $3(18.8)$ & 0.70 & 0.28 & 0.40 \\
\hline Computer tomography, (n) & 5 & 1 & 2 & 3 & & & \\
\hline Unilobar infiltrate, n (\%) & $2(40.0)$ & $0(0.0)$ & $0(0.0)$ & $0(0.0)$ & 1.00 & 0.95 & 0.71 \\
\hline Multilobar infiltrates, n (\%) & $2(40.0)$ & $1(100.0)$ & $2(100.0)$ & $3(100.0)$ & 1.00 & 0.57 & 0.36 \\
\hline Ground glass opacity, n (\%) & $0(0.0)$ & $0(0.0)$ & $1(50.0)$ & $0(0.0)$ & $\mathrm{n} / \mathrm{a}$ & 0.57 & $\mathrm{n} / \mathrm{a}$ \\
\hline Pleural effusion, n (\%) & $2(40.0)$ & $1(100.0)$ & $1(50.0)$ & $2(66.7)$ & 1.00 & 1.00 & 1.00 \\
\hline Normal, n (\%) & $1(20.0)$ & $0(0.0)$ & $0(0.0)$ & $0(0.0)$ & 1.00 & 1.00 & 1.00 \\
\hline
\end{tabular}


Table 13 Radiological findings for all patients

\begin{tabular}{|c|c|c|c|c|c|c|c|}
\hline & $\begin{array}{l}\text { Viral } \\
(n=80)\end{array}$ & $\begin{array}{l}\text { Bacterial } \\
(n=42)\end{array}$ & $\begin{array}{l}\text { Mixed } \\
(n=11)\end{array}$ & $\begin{array}{l}\text { No pathogen } \\
(n=121)\end{array}$ & Viral vs. bacterial & $\begin{array}{l}p \text {-value } \\
\text { Viral vs. mixed }\end{array}$ & Viral vs. no pathogen \\
\hline X-ray, (n) & 61 & 32 & 10 & 97 & & & \\
\hline Unilobar infiltrate, n (\%) & $15(24.6)$ & $5(15.6)$ & $1(10.0)$ & $16(16.5)$ & 0.32 & 0.57 & 0.21 \\
\hline Multilobar infiltrates, n (\%) & $12(19.7)$ & $12(37.5)$ & $6(60.0)$ & $36(37.1)$ & 0.06 & 0.03 & 0.02 \\
\hline Interstitial infiltrates, n (\%) & $5(8.2)$ & $8(25.0)$ & $2(20.0)$ & 19 (19.6) & 0.06 & 0.51 & 0.05 \\
\hline Pleural effusion, n (\%) & $9(14.8)$ & $13(40.6)$ & $1(10.0)$ & $26(26.8)$ & 0.01 & 1.00 & 0.08 \\
\hline Normal, n (\%) & $18(29.5)$ & $3(9.4)$ & $1(10.0)$ & $17(17.5)$ & 0.03 & 0.37 & 0.08 \\
\hline Computer tomography, (n) & 28 & 30 & 7 & 74 & & & \\
\hline Unilobar infiltrate, n (\%) & $7(25.0)$ & $4(13.3)$ & $0(0.0)$ & $7(9.5)$ & 0.26 & 0.35 & 0.10 \\
\hline Multilobar infiltrates, n (\%) & $13(46.4)$ & $17(56.7)$ & $6(85.7)$ & $35(47.3)$ & 0.44 & 0.14 & 0.94 \\
\hline Ground glass opacity, n (\%) & $4(14.3)$ & $6(20.0)$ & $3(42.9)$ & $29(39.2)$ & 0.82 & 0.25 & 0.02 \\
\hline Pleural effusion, n (\%) & $7(25.0)$ & $14(46.7)$ & $2(28.6)$ & $27(36.5)$ & 0.09 & 1.00 & 0.28 \\
\hline
\end{tabular}

$n$ number. Multiple findings were counted individually

${ }^{a}$ Mantel-Haenszel chi square test or Fisher exact test were used

1136 children showed that the introduction of an expanded multiplex rtPCR had a shorter turnaround time and decreased the duration of antibiotic use (2.8 vs. 3.2 days; $p=0.003$ ) without reducing the proportion of antibiotic prescriptions [26].

As in most previous studies, typical respiratory bacteria were not included in the test panel. Due to this technical limitation, missing a treatable pathogen is of concern in light of potential bacterial-viral co-infections $[3,7-13,16-19]$. It was shown that clinical suspicion of a bacterial super-infection was one reason for physicians to not stop antibiotics in rtPCR-positive patients [3]. We tried to partially overcome this by creating categories of clinically bacterial and clinically viral infections. This definition, aided by providing a biomarker criterion, accounted for the possibility of a viral infection in the setting of bacterial carriage. One of the major differences and advantages of the current study compared to previous publications is that it not only assessed the impact of the rtPCR results, which themselves had a limited impact on appropriate therapy, but it also integrated other 'real-world' clinical and radiologic parameters into the decision process.

Table 14 Prediction of respiratory virus detection for adult patients

\begin{tabular}{|c|c|c|c|c|}
\hline \multirow[b]{2}{*}{ Predictor } & \multicolumn{2}{|c|}{ Univariable analysis } & \multicolumn{2}{|c|}{ Multivariable analysis } \\
\hline & $p$-value & OR $(95 \%$ Cl) & $p$-value & OR $(95 \% C l)$ \\
\hline Neutropenia & 0.01 & $3.46(1.32-9.07)$ & 0.27 & $2.11(0.56-7.89)$ \\
\hline $\begin{array}{l}\text { Hematologic } \\
\text { malignancy }\end{array}$ & 0.04 & $2.25(1.02-4.97)$ & 0.59 & $1.35(0.45-4.01)$ \\
\hline Pleural effusion & 0.02 & $0.36(0.15-0.86)$ & 0.02 & $0.31(0.12-0.80)$ \\
\hline $\begin{array}{l}\text { Platelets } \\
\text { (minimum), G/l }\end{array}$ & 0.02 & $1.00(0.99-1.00)$ & 0.20 & $1.00(0.99-1.00)$ \\
\hline
\end{tabular}

Advanced molecular diagnostic tests have to be interpreted in the context of available clinical and diagnostic information in order to improve clinical management. The results confirmed the important role of clinical judgement for appropriate antibiotic prescriptions, with rtPCR providing additional information rather than being solely responsible for treatment decisions.

Quantification of genomic viral load might improve specificity of virus detection, with higher organism burden being associated with higher risk of complications and severe disease in adults and children [27, 28]. Unfortunately, quantitative results were not available with the applied assay. Similarly, optimal timing of molecular testing in relation to symptom onset and inclusion of an ever-expanding number of respiratory viruses might be important to further increase sensitivity [27]. However, to the authors' knowledge, it has not yet been studied whether either of these two factors would improve clinical management.

A pathogen was identified in 140 (55\%) patients in this study, in accordance with detection rates in other studies ranging from 38 to $82 \%$ [4, 12, 17, 19, 20, 22, 29-35]. A mixed bacterial-viral etiology was found in 11 (8\%)

Table 15 Prediction of respiratory virus detection for pediatric patients

\begin{tabular}{|c|c|c|c|c|}
\hline \multirow[b]{2}{*}{ Predictor } & \multicolumn{2}{|c|}{ Univariable analysis } & \multicolumn{2}{|c|}{ Multivariable analysis } \\
\hline & $p$-value & OR $(95 \%$ Cl) & $p$-value & OR $(95 \% \mathrm{Cl})$ \\
\hline Neutropenia & 0.06 & $7.75(0.92-65.66)$ & 0.10 & $7.44(0.69-80.42)$ \\
\hline $\begin{array}{l}\text { Multilobular } \\
\text { infiltrates }\end{array}$ & 0.03 & $0.31(0.11-0.91)$ & 0.02 & $0.22(0.06-0.81)$ \\
\hline $\begin{array}{l}\text { White blood cells } \\
\text { (maximum), G/l }\end{array}$ & 0.02 & $0.94(0.89-0.99)$ & 0.10 & $0.95(0.90-1.01)$ \\
\hline
\end{tabular}


patients. Previously described rates varied between 2 and $23 \%$ [17, 19, 22, 29-35]. Some studies suggested that mixed bacterial-viral infections result in more severe clinical diseases (as measured by the CURB-65 score or the pneumonia severity index) $[17,34]$, a higher rate of mechanical ventilation, longer duration of ICU care [36, 37], longer hospital stays [22, 36], or higher mortality [37, 38], while other studies did not [29, 39, 40]. In this study, mixed bacterial-viral infections were associated with a higher rate of ICU admission and mechanical ventilation compared to pure viral $(p=0.05 ; p=0.005)$ and pure bacterial $(p=0.06$; $p=0.19$ ) infections if all patients were considered. However, these results should not be viewed as representative of the etiology of lower RTI in East Switzerland as these hospitals presented a preselected group of patients.

In agreement with the findings of some studies [20, $22,34]$ and in contrast to others [7, 29, 39], this study failed to identify specific predictors of viral detection in multivariate logistic regression. Advancing age was previously described as more common in viral infections [19, $22,29,35]$ but the evidence is inconclusive [31, 32]. In this study, younger age was a significant predictor of virus detection in univariable logistic regression if all patients were considered, but not in stratified analyses in children and adults. The mean age in the group with respiratory viral infections was lower than in the remaining patients ( 29 vs. 47 years; $p<0.001$ ) but the differences were not significant if stratified for children and adults.

There are some limitations to the study. First, the change of anti-infective management was retrospectively matched with the date of the rtPCR analysis. Exact time specifications were not available, leaving room for potential inaccuracies. It is not known whether and to what extent these or other factors contributed to the clinical decisions in starting, stopping, or continuing antibiotic therapy. Due to the retrospective nature of the study, it was not possible to consider the clinical presentation in the analysis. Therefore, it was difficult to reproduce the decision-making process and the primary indication for antibiotic therapy. This is an important limitation because clinical judgement remains essential concerning the use of antibiotics [41]. Furthermore, data on the consequences of rtPCR results on antibiotic treatment are difficult to obtain in the ambulatory setting, which explains the relatively small number of enrolled outpatients. Prospective studies or ideally RCTs will be necessary to confirm the findings.

Second, creating categories of clinically bacterial and clinically viral etiology by means of biomarker, radiologic presentations and antibiotic pre-treatment was done arbitrarily to reflect real-life decision-making. These theoretical reflections were important to better understand the findings; however, and as noted above, retrospectively the actual decision-making process remained unclear.
Third, the study included patients with upper and lower respiratory tract infections and did not exclude patients with antibiotic pre-treatment or significant underlying pathologic conditions, which may have biased the results but reflects clinical routine. Not having algorithms in place when to perform rtPCR testing or how to apply the results likewise mirrors the real-world scenario.

Fourth, the study's multiplex rtPCR only included respiratory viruses. Newer generation assays additionally cover atypical and typical bacteria and increase the detection of potential respiratory pathogens, albeit with yet unresolved specificity issues as these typical bacterial pathogens might also represent carriage in the absence of disease [42].

Fifth, the prevalence of RSV was underestimated in this study. In the population of hospitalized children, rapid detection tests for RSV were performed initially and, if positive, no additional rtPCR was performed. Because the study included only patients in whom an rtPCR assay for respiratory viruses was performed, the number of RSV infections was lower than expected from epidemiological data.

\section{Conclusion}

This study reveals the real-life impact of viral multiplex rtPCR in both children and adults, which was more limited in adults but improved when results were seen in the context of biomarkers, radiology, and antibiotic pretreatment. As substantial reduction of unnecessary antibiotic prescriptions seems possible, it will be necessary to develop more structured management algorithms incorporating molecular diagnostics including bacterial pathogens, which need to be prospectively tested in their efficacy and safety in RTI.

\section{Abbreviations \\ CRP: C-reactive protein; CT: Computer tomography; CXR: Chest radiograph; ICU: Intensive care unit; IQR: Interquartile range; LOS: Length of stay; \\ PCT: Procalcitonin; RCT: Randomized controlled trial; RSV: Respiratory syncytial virus; RTI: Respiratory tract infection; rtPCR: Real-time polymerase chain reaction; SIRS: Systemic inflammatory response syndrome; WBC: White blood cells count}

\section{Acknowledgements}

We are grateful to the laboratory team and the archive staff of Kantonsspital St. Gallen and Children's hospital of Eastern Switzerland for providing the necessary data. We thank Michael Mayer for input in statistics.

\section{Funding}

The study was funded by the Department of Infectious Diseases and Hospital Epidemiology, Kantonsspital St. Gallen and Children's Hospital of Eastern Switzerland.

Availability of data and materials

The dataset supporting the conclusions of this article can be obtained from the authors upon request.

Authors' contributions

All the authors met authorship criteria. LMM, WCA, CK conceived the study, generated and designed the research plan. Data collection was performed by LMM. Data analysis was conducted by LMM and supervised by WCA. CK, 
FR and PV assisted with the clinical interpretation of the data. LMM and WCA wrote the first draft of the manuscript. All authors critically reviewed the manuscript for important intellectual content and agreed with the manuscript results and conclusions. All read and approved the final manuscript.

\section{Competing interests}

The authors declare that they have no competing interests.

\section{Ethics approval and consent to participate}

The study was approved by the cantonal ethics review board (EKSG 14/140). Due to the retrospective nature of the study, informed consent was waived.

\section{Author details}

${ }^{1}$ School of Medicine, University of Basel, Klingelbergstasse 61, 4056 Basel, Switzerland. ${ }^{2}$ Children's Hospital of Eastern Switzerland, Claudiusstrasse 6, 9006 St. Gallen, Switzerland. ${ }^{3}$ Clinic for Pulmonology \& Sleep Medicine, Kantonsspital St. Gallen, Rorschacherstrasse 95, 9007 St. Gallen, Switzerland. ${ }^{4}$ Division of Infectious Diseases \& Hospital Epidemiology, Kantonsspital St. Gallen, Rorschacherstrasse 95, 9007 St. Gallen, Switzerland.

Received: 4 October 2016 Accepted: 18 January 2017

Published online: 25 February 2017

\section{References}

1. Musher DM, Roig IL, Cazares G, Stager CE, Logan N, Safar H. Can an etiologic agent be identified in adults who are hospitalized for community-acquired pneumonia: results of a 1-year study. J Infect. 2013;67:11-8. doi:10.1016/j.jinf. 2013.03.003.

2. Lieberman D, Korsonsky I, Ben-Yaakov M, Lazarovich Z, Friedman MG, Dvoskin B, et al. A comparative study of the etiology of adult upper and lower respiratory tract infections in the community. Diagn Microbiol Infect Dis. 2002;42:21-8.

3. van de Pol AC, Wolfs TF, Tacke CE, Uiterwaal CS, Forster J, Van Loon AM, et al. Impact of PCR for respiratory viruses on antibiotic use: theory and practice. Pediatr Pulmonol. 2011;46:428-34. doi:10.1002/ppul.21385.

4. Wishaupt JO, Russcher A, Smeets LC, Versteegh FG, Hartwig NG. Clinical impact of RT-PCR for pediatric acute respiratory infections: a controlled clinical trial. Pediatrics. 2011;128:e1113-20. doi:10.1542/peds.2010-2779.

5. Creer DD, Dilworth JW, Gillespie SH, Johnston AR, Ling C, Patel S, et al. Aetiological role of viral and bacterial infections in acute adult lower respiratory tract infection (LRTI) in primary care. Thorax. 2006;61:75-9.

6. Rhedin S, Lindstrand A, Rotzén-Östlund M, Tolfvenstam T, Ohrmalm L, Rinder MR, et al. Clinical utility of PCR for common viruses in acute respiratory illness. Pediatrics. 2014;133:e538-45. doi:10.1542/peds.2013-3042.

7. Oosterheert JJ, Van Loon AM, Schuurman R, Hoepelman Al, Hak E, Thijsen S, et al. Impact of rapid detection of viral and atypical bacterial pathogens by real-time polymerase chain reaction for patients with lower respiratory tract infection. Clin Infect Dis. 2005;41:1438-44.

8. van de Pol AC, Wolfs TF, Jansen NJ, Van Loon AM, Rossen JW. Diagnostic value of real-time polymerase chain reaction to detect viruses in young children admitted to the pediatric intensive care unit with lower respiratory tract infection. Crit Care. 2006;10:R61.

9. Nolte FS. Molecular diagnostics for detection of bacterial and viral pathogens in community-acquired pneumonia. Clin Infect Dis. 2008;47:S123-6. doi:10. 1086/591392.

10. Templeton KE, Scheltinga SA, van den Eeden WC, Graffelman AW, van den Broek PJ, Claas EC. Improved diagnosis of the etiology of communityacquired pneumonia with real-time polymerase chain reaction. Clin Infect Dis. 2005;41:345-51.

11. Sanghavi SK, Bullotta A, Husain S, Rinaldo CR. Clinical evaluation of multiplex real-time PCR panels for rapid detection of respiratory viral infections. J Med Virol. 2012;84:162-9. doi:10.1002/jmv.22186.

12. Johansson N, Kalin M, Tiveljung-Lindell A, Giske CG, Hedlund J. Etiology of community-acquired pneumonia: increased microbiological yield with new diagnostic methods. Clin Infect Dis. 2010;50:202-9. doi:10.1086/648678.

13. Ruuskanen $\mathrm{O}$, Lahti $\mathrm{E}$, Jennings LC, Murdoch DR. Viral pneumonia. Lancet. 2011;377:1264-75. doi:10.1016/S0140-6736(10)61459-6.

14. Martin ET, Fairchok MP, Stednick ZJ, Kuypers J, Englund JA. Epidemiology of multiple respiratory viruses in childcare attendees. J Infect Dis. 2013;207: 982-9. doi:10.1093/infdis/jis934.
15. Walsh EE, Peterson DR, Kalkanoglu AE, Lee FE, Falsey AR. Viral shedding and immune response to respiratory syncytial virus infection in older adults. J Infect Dis. 2013;207:1424-32. doi:10.1093/infdis/jit038.

16. Bakaletz LO. Viral potentiation of bacterial superinfection of the respiratory tract. Trends Microbiol. 1995;3:110-4.

17. Falsey AR, Becker KL, Swinburne AJ, Nylen ES, Formica MA, Hennessey PA, et al. Bacterial complications of respiratory tract viral illness: a comprehensive evaluation. J Infect Dis. 2013;208:432-41. doi:10.1093/infdis/jit190.

18. De Roux A, Ewig S, García E, Marcos MA, Mensa J, Lode H, et al. Mixed community-acquired pneumonia in hospitalised patients. Eur Respir J. 2006; 27:795-800.

19. Van Gageldonk-Lafeber AB, Wever PC, van der Lubben IM, De Jager CP, Meijer $A$, De Vries MC, et al. The etiology of community-acquired pneumonia and implications for patient management. Neth J Med. 2013;71:418-25.

20. Brittain-Long R, Westin J, Olofsson S, Lindh M, Andersson LM. Access to a polymerase chain reaction assay method targeting 13 respiratory viruses can reduce antibiotics: a randomised, controlled trial. BMC Med. 2011;9:44 doi:10.1186/1741-7015-9-44.

21. Stolz D, Christ-Crain M, Gencay MM, Bingisser R, Huber PR, Müller B, et al. Diagnostic value of signs, symptoms and laboratory values in lower respiratory tract infection. Swiss Med Wkly. 2006;136:434-40.

22. Huijskens EG, Koopmans M, Palmen FM, Van Erkel AJ, Mulder PG, Rossen JW. The value of signs and symptoms in differentiating between bacterial, viral and mixed etiology in patients with community-acquired pneumonia. Jed Microbiol. 2014;63:441-52. doi:10.1099/jmm.0.067108-0.

23. Ambrosioni J, Bridevaux PO, Wagner G, Mamin A, Kaiser L. Epidemiology of viral respiratory infections in a tertiary care centre in the era of molecular diagnosis, Geneva, Switzerland, 2011-2012. Clin Microbiol Infect. 2014;20: O578-84. doi:10.1111/1469-0691.12525.

24. Bone RC, Balk RA, Cerra FB, Dellinger RP, Fein AM, Knaus WA, et al. Definitions for sepsis and organ failure and guidelines for the use of innovative therapies in sepsis. The ACCP/SCCM Consensus Conference Committee. American College of Chest Physicians/Society of Critical Care Medicine. Chest. 1992;101:1644-55.

25. Goldstein B, Giroir B, Randolph A. International pediatric sepsis consensus conference: definitions for sepsis and organ dysfunction in pediatrics. Pediatr Crit Care Med. 2005;6:2-8.

26. Rogers BB, Shankar P, Jerris RC, Kotzbauer D, Anderson EJ, Watson JR, et al. Impact of a rapid respiratory panel test on patient outcomes. Arch Pathol Lab Med. 2015;139:636-41. doi:10.5858/arpa.2014-0257-OA.

27. Lee N, Chan MCW, Lui GCY, Li R, Wong RYK, Yung IMH, et al. High viral load and respiratory failure in adults hospitalized for respiratory syncytial virus infections. J Infect Dis. 2015;212(8):1237-40. doi:10.1093/infdis/jiv248.

28. Hasegawa K, Jartti T, Mansbach JM, Laham FR, Jewell AM, Espinola JA, et al. Respiratory syncytial virus genomic load and disease severity among children hospitalized with bronchiolitis: Multicenter cohort studies in the United States and Finland. J Infect Dis. 2015;211(10):1550-9. doi:10.1093/ infdis/jiu658.

29. Johnstone J, Majumdar SR, Fox JD, Marrie TJ. Viral infection in adults hospitalized with community-acquired pneumonia: prevalence, pathogens, and presentation. Chest. 2008;134:1141-8. doi:10.1378/chest.08-0888.

30. Cillóniz C, Ewig S, Polverino E, Marcos MA, Esquinas C, Gabarrús A, et al. Microbial etiology of community-acquired pneumonia and its relation to severity. Thorax 2011; 66: 340-346. Thorax. 2011;66:340-6. doi:10.1136/thx.2010.143982.

31. Viasus D, Marinescu C, Villoslada A, Cordero E, Gálvez-Acebal J, Fariñas MC, et al. Community-acquired pneumonia during the first post-pandemic influenza season: a prospective, multicentre cohort study. J Infect. 2013;67: 185-93. doi:10.1016/j.jinf.2013.05.006.

32. Michelow IC, Olsen K, Lozano J, Rollins NK, Duffy LB, Ziegler T, et al. Epidemiology and clinical characteristics of community-acquired pneumonia in hospitalized children. Pediatrics. 2004;113:701-7.

33. Choi SH, Hong SB, Ko GB, Lee Y, Park HJ, Park SY, et al. Viral infection in patients with severe pneumonia requiring intensive care unit admission. Am J Respir Crit Care Med. 2012;186:325-32. doi:10.1164/rccm.201112-22400C.

34. Jennings LC, Anderson TP, Beynon KA, Chua A, Laing RT, Werno AM, et al. Incidence and characteristics of viral community-acquired pneumonia in adults. Thorax. 2008:63:42-8.

35. Jain S, Self WH, Wunderink RG, Fakhran S, Balk R, Bramley AM, et al. CommunityAcquired Pneumonia Requiring Hospitalization among U.S. Adults. N Engl J Med. 2015;373:415-27. doi:10.1056/NEJMoa1500245.

36. Ghani AS, Morrow BM, Hardie DR, Argent AC. An investigation into the prevalence and outcome of patients admitted to a pediatric intensive care 
unit with viral respiratory tract infections in Cape Town, South Africa. Pediatr Crit Care Med. 2012;13:e275-81. doi:10.1097/PCC.0b013e3182417848.

37. Rice TW, Rubinson L, Uyeki TM, Vaughn FL, John BB, Miller 3rd RR, et al. Critical illness from 2009 pandemic influenza A virus and bacterial coinfection in the United States. Crit Care Med. 2012;40:1487-98. doi:10.1097/CCM. 0b013e3182416f23.

38. Diederen BM, Van Der Eerden MM, Vlaspolder F, Boersma WG, Kluytmans JA, Peeters MF. Detection of respiratory viruses and Legionella spp. by real-time polymerase chain reaction in patients with community acquired pneumonia. Scand J Infect Dis. 2009;41:45-50. doi:10.1080/00365540802448799.

39. Bello S, Mincholé E, Fandos S, Lasierra AB, Ruiz MA, Simon AL, et al. Inflammatory response in mixed viral-bacterial community-acquired pneumonia. BMC Pulm Med. 2014;14:123. doi:10.1186/1471-2466-14-123.

40. Marcos MA, Camps M, Pumarola T, Martinez JA, Martinez E, Mensa J, et al. The role of viruses in the etiology of community-acquired pneumonia in adults. Antivir Ther. 2006;1 1(3):351-9.

41. Filice GA, Drekonja DM, Thurn JR, Hamann GM, Masoud BT, Johnson JR. Diagnostic Errors that Lead to Inappropriate Antimicrobial Use. Infect Control Hosp Epidemiol. 2015;36:949-56. doi:10.1017/ice.2015.

42. Gadsby NJ, Russell CD, Mchugh MP, Mark H, Conway Morris A, Laurenson IF, et al. Comprehensive molecular testing for respiratory pathogens in communityacquired pneumonia. Clin Infect Dis. 2016;62(7):817-23. doi:10.1093/cid/civ1214.

\section{Submit your next manuscript to BioMed Central} and we will help you at every step:

- We accept pre-submission inquiries

- Our selector tool helps you to find the most relevant journal

- We provide round the clock customer support

- Convenient online submission

- Thorough peer review

- Inclusion in PubMed and all major indexing services

- Maximum visibility for your research

Submit your manuscript at www.biomedcentral.com/submit 